Hoarding Of International Reserves And Sterilization In Dollarized And Indebted Countries: an effective monetary policy?

Layal Mansour 


\section{GATE Groupe d'Analyse et de Théorie Économique Lyon-St Étienne}

93, chemin des Mouilles 69130 Ecully - France

Tel. +33(0)4 72866060

Fax $+33(0) 472866090$

6, rue Basse des Rives 42023 Saint-Etienne cedex 02 - France

Tel. +33 (0)4 77421960

Fax. +33 (0)4 77421950

Messagerie électronique / Email : gate@gate.cnrs.fr

Téléchargement / Download : http://www.gate.cnrs.fr - Publications / Working Papers 


\title{
Hoarding Of International Reserves And Sterilization In Dollarized And Indebted Countries : an effective monetary policy?
}

\section{Layal MANSOUR}

Ph.D Student

Université Lyon 2, Lyon, F-69007, France ;

CNRS, GATE Lyon St Etienne, Ecully, F-69130,

mansour@gate.cnrs.fr

\begin{abstract}
The primary aim of this paper is to explore the effectiveness of Hoarding International Reserves and Sterilization in dollarized and indebted countries such as Turkey and Lebanon, by measuring the sterilization coefficient, and the offset coefficient. It also focuses on exploring the link between the sources of Reserves and the external debt. Using monthly data collected from the International Monetary Fund and from the Central Banks of Turkey and Lebanon between January 1994 and February 2011, we applied a 2SLS regression models and we identified explanatory variables that enabled us to estimate the aforementioned coefficients. Our results showed that despite their theoretical practice of sterilization policy, economic constrains of these countries contribute to weaken the efficacy expected from monetary policies.
\end{abstract}

Keywords: Monetary policy, International Reserve, Sterilization, Foreign Liabilities, Dollarized countries, Turkey, Lebanon.

Politique monetaire, Reserves internationales, Stérilisation, pays dollariseé, Turquie, Liban. JEL: E52, E58, F30, F34 


\section{Introduction}

Hoarding of international reserves (IR) is often conceived as exclusive to the emerging market countries (EMC). They share around 65\% of global reserves in 2008. In 2010, six Asian countries ${ }^{1}$ were among the world's largest holder of IR. This increasing trend became remarkable in the post-crisis era in Eastern Asia and Latin America (Figure 1). The basic source of the IR growth is the persistent current account surplus. The first mainly reason for the course of hoarding IR, as described by Aizenman and Marion (2004), Calvo (2006), Aizenman et Lee $(2008,2010)$ and Aizenman et al (2011), is that it offers a precautionary self-insurance against financial crisis ${ }^{2}$. In fact, those countries have suffered from sudden stop crisis that caused a psychological impact ${ }^{3}$ in the region, and so made EMC look for a build up ample war chest of IR to protect themselves eventually against a new same type of crisis. The second mainly reason of hoarding IR is that it occurs a mercantilist export promotion. This means that buying foreign currencies permit to hold down domestic currencies and therefore improve external competitiveness and promote exports. Finally, Calvo and Reinhart (2002) explain that growth of IR offer exchange rate stability after systematic foreign market interventions.

The process of hoarding IR is followed by a policy called sterilization. When a Central Bank (CB) decides to buy IR, it will either add to the fund by increasing the Reserve of Monetary Base (MB) also known as Reserve Money (RM), which is potentially inflationary, or reduces its Net Domestic Assets (NDA), which sterilize/neutralize the impact on Reserve of $\mathrm{MB}^{4}$. Countries that hoard IR also sterilize them; this trend became apparent in the 90s (figure 2). Therefore hoarding IR and Sterilization consist of complementary policies. The success of hording IR was so remarkable in the recent years that accumulation of IR became more desirable. Thus, countries post crisis which were previously expressing the "fear of floating" described by Calvo and Reinhart, (2002), are nowadays expressing the "fear of loosing International Reserves" as mention by Aizenman and Lee (2010).

However, the efficiency of these policies is not automatically guaranteed. First, the implementation of the monetary policy should be compatible and match with the internal

\footnotetext{
${ }^{1}$ China, India, Taipei, Korea, Singapore and Hong-Kong.

${ }^{2}$ According to these authors, International reserves are considered as buffer stock, which allows greater flexibility of exchange rates and provides domestic authority with access to hard currency to cover basic living expenses and mitigate to adverse consequences of capital flight.

${ }^{3}$ Expression used by Aizenman et al 2011

${ }^{4}$ Indeed, the Central Bank can bring out the effect of hoarding on the monetary base in several ways, including the sale market instruments such as government bonds or use the swap or other.
} 
economy of the country and respect the context of Mundell Trilemma ${ }^{5}$, called by Obsfeld et al (2004) "The guide of the political structure". In addition to the latter, the financial markets must be developed and the instruments used in sterilization should be liquid, otherwise, according to Caballero and Krishnamurthy (2001), IR and sterilization policies become a sort of "International Liquidity Illusion". Second, as proved in several studies of authors cited above, the domestic and foreign bonds should be perfect substitute and the domestic interest rate should be less than the international one (otherwise the interest cost of sterilization bond becomes unsustainable). Finally, an adequate level of hoarding IR for every country should be determined $^{6}$. The "Grennspan-Guidotti" Rule" was considered as the most adherents and empirical support, which consists of hoarding IR that exceeds the total short-term external $\mathrm{debt}^{8}$. Recently, Obsfedl et al (2009) mentioned that despite the focus on the "GuidottiGreenspan" rule and sudden stops in the literature, short term external debt is not a significant predictor of reserve holdings, though another variable often considered in more traditional models, the Trade/GDP ratio is. Briefly, either the first or the second ratio, the inclusion of Trade Balance and external debt should be considered.

Some countries like Lebanon and Turkey are sharing the same post-crisis EMC behavior: increasing the ratio of IR/GDP with sterilization (figure 3 and figure 4). Turkey and Lebanon are considered between the highest holder of IR, ranked respectively the $17^{\text {th }}$ and $27^{\text {th }}$ if adding Gold ${ }^{9}$. The IR minus gold in GDP ratio in Turkey exceeds the $30 \%$, and about $70 \%$ for Lebanon. The latter is considered having the $9^{\text {th }}$ highest IR/GDP ratio in the world ${ }^{10}$ exceeding the ratio in China, Malaysia, Korea, and some other EMC. But Turkey and Lebanon internal economic structure are basically different from the EMC; suffering from almost the pre-crisis EMC flaws: 1- An important deficit Balance of Payment (Figure 5) which deplete the stock of reserves and/or forces monetary authority to borrows reserves. 2A high foreign liabilities (Figure 6) which reduce the efficacy of IR as explained above and excessively. 3- A dollarization rate (financial dollarization and/or currency substitution) going from about $30 \%$ in Turkey to $70 \%$ in Lebanon; due to the degree of country trust and

\footnotetext{
${ }^{5}$ Mundell Trilemma explained the impossible to match simultaniously financial integration, and stability of exhange rates with a monetary independance.

${ }^{6}$ The ratio IR on Gross Domestic Product (GDP) can only determine a measure of IR accumulation, but this ratio cannot express the adequate level of hoarding IR

${ }^{7}$ Former chairman of the Federal Reserve Board, Alan Greenspan, and former deputy minister of finance for Argentina, Pablo Guidotti, published an academic paper in 1999 that suggested, to avoid a default, a country needs to maintain hard currency reserves equal to at least $100 \%$ of their short-term (maturing in the next 12 months) foreign debt.

${ }^{8}$ Inn Jeanne and Rancière, 2009

${ }^{9}$ According to the CIA World Factbook, 2011

${ }^{10}$ If we add gold hold by the Central Bank (excluding the part in the IMF and UCB), Lebanon becomes the 3th holder in the world on international reserves relatively on his GDP.
} 
currency trust. Thus, the condition of perfect substitutability of domestic bonds and foreign bonds is rejected. Eishengreen and Hausman (1999) and several authors later, called the two last cases using the term of « Original $\operatorname{Sin}^{11}$ », to describe the impossibility for a country to borrow abroad in its local currency and its risky consequences.

Lebanon and Turkey are a sample of countries that are facing a paradox between the buffer stock expected by accumulating and sterilizing IR; and the possible vulnerability to crisis expected by the Original Sin.

Most of the previous studies focused on the exchange rate regime and the interest rate (the interest rate and its evolution is related to the exchange rate regime) to conclude conditions of efficiency of IR and sterilization monetary policy. In this paper, we emphasized on the foreign liabilities and the dollarization rate. Using a 2SLS regression model, we estimated, the sterilization coefficient of Lebanon and Turkey, which influence sterilization function (sterilization coefficient). We also estimated the offset coefficient of the capital flow equation, consisting of measuring the fraction of policy-induced change in the bank reserves, which is offset through the capital account. We concluded that although monetary policy of sterilization seems to be practiced like as seen in the EMC, the offset indicated the ineffectiveness of such application. More precisely, the "Original Sin" characteristics affect the monetary policy and contribute in the reduction of the effectiveness of the monetary policies that are being used. In addition, by decomposing the source of Foreign Reserves inflows, we found that monetary authority integrate partially the external debt, which defy the basic and theoretical definition of capital inflows of EMC.

\footnotetext{
${ }^{11}$ Until 2005 definition of "original sin" has been modified several times by Eishengreen and Hausmann with eother authors and it now associated to dollarized countries with foreign liabilities.
} 


\section{THEORITICAL FRAMEWORKS}

The formal empirical investigations and interpretations of the relationship between inflows, sterilization and monetary policy efficiency are usually described in the literature by the estimation of the sterilization coefficient, and the offset coefficient. Based on the framework of Herring and Marston (1977), Kouri and Porter (1974) and Cumby and Obsfeld (1982), the sterilization coefficient consist on estimating the sterilization function; while the offset coefficient consist on evaluating the degree of what the central bank's activities in the domestic market spurred additional capital inflows.

\subsection{Sterilization Function}

We Expressed the sterilization function called in several studies "monetary policy reaction function" from changes in NDA held by monetary authorities, and of changes of capital inflows NFA coming from abroad:

$\triangle N D A=\alpha_{+} \beta \Delta N F A+\delta_{i} X_{i}+\varepsilon_{i}$

Where $\mathrm{X}_{\mathrm{i}}$ represent other exogenous variables, which can affect the equation of the sterilization function. Xi variables reflect the effects of monetary policy. Thus, knowing that $B_{1}$ is a parameter that determines the decisions of monetary authorities regarding sterilization, we deduce that:

If $\beta=-1, \triangle N F A$ represents a full sterilization of reserves. The $C B$ grants domestic credits to facilitate the increase of money demand (due to GDP growth) but prevents the expansion of domestic credit from NFR. This means that every unit of foreign exchange purchased by the $\mathrm{CB}$ (the increase of NFA) through its intervention in the foreign exchange market which should creates RM, will be neutralized; and thus, the created money will be withdrawn (decrease of NDA) from the market, and consequently, the change in RM will be equal to zero. If $\beta=0$, there is no practice of sterilization. In other words, every net inflow or net outflow of foreign capital will result in an equal change in the domestic money supply. If -1 $<\beta<0$, there is a partial sterilization. If $\beta<-1$, this indicates a tighter monetary policy due to a greater interest about inflation. In this case, possession of a unit of foreign reserves will reduce domestic assets held by the $\mathrm{CB}$ of more than one unit and therefore reduce the $\mathrm{MB}$. If $\beta>0$, we are in an economy of expansionary monetary policy because of concerns about "credit crunch" or exposure to a systemic crisis. 


\subsection{Capital-flow Equation}

We studied another aspect of the interdependence of capital inflows and monetary measures called the capital-flow equation. We estimated the impact of the Change in Net Domestic Asset ( $\triangle N D A)$ on Changes in Net Foreign Asset ( $\triangle N F A)$ : offset coefficient. The offset coefficient indicates the fraction of any domestic credit expansion reserved by the CB foreign reserve losses in the same period and the sterilization coefficient indicates the degree of sterilization which is offset in the inflows so as to leave the overall money supply unaffected through open market operations or some other monetary regulations like reserve requirements. The NFA becomes the dependent, which represent the $\triangle$ NFA in the CB's NFA as a proxy for capital inflows, while the main explanatory variable is $\triangle \mathrm{NDA}$, reflecting the effects of monetary policy. Other exogenous variables can affect capital inflows are represented by vector $Z_{\mathrm{i}}$ in the equation: $\Delta N F A=\boldsymbol{\beta}^{\top} \Delta N D A+\delta^{\prime} Z_{i .}+\varepsilon_{i}$.

Where $\beta$ ' is the offset coefficient and its value ranges between "- 1 " and " 0 ". If $\beta$ ' is around zero, there is no capital mobility. The change in $\triangle$ NDA affects the overall money supply, which means that the impact of activities undertaken by the CB partially or fully "remains" in the system. If $\beta^{\prime}=-1$ there is a perfect capital mobility, in other words, every reduction in NDA is compensated by an equal increase in NFA, while the supply of money in the system remains unchanged and vice versa; thus, sterilization becomes ineffective, as described by Christensen (2004).

\subsection{Sources of Foreign Reserves}

Theoretically, inflows coming from abroad are from Current account (CA) and capital account (K). Therefore, $\Delta N D A=\alpha(C A+K)+\delta_{i} X_{i}+\varepsilon_{i}$

Considering that the Balance of Payment (BP) is the sum of CA balance and $\mathrm{K}$ balance $(\mathrm{CA}+$ $\mathrm{K}$ ) and it is equal to the change in the central bank's NFA, which is approximated by the change in Foreign Reserve. The function (2) becomes written like function (1). Based on the study of Aizenman and Glick ${ }^{12}$ (2008), we estimated the essential sources of NFA, by expressing the change in the NDA using the fallowing equation:

$\Delta N D A=\alpha_{1}+\beta C A+\delta_{1} K a l+\delta_{i} X_{i}+\varepsilon_{i}$

Contrary to EMCA such as China, Singapore, Brazil, Malaysia and others that have excess in their commercial balance, Lebanon and Turkey are characterized by a BP deficit; Aizenman and Glick (2008) divided the NFA into CA, and K. As for Lebanon and Turkey, we

\footnotetext{
${ }^{12}$ In their work, Aizenman and Glick (2008) they even divided K into Foreign Direct Investment (FDI) and Non Foreign Direct Investment (NFDI).
} 
considered in this paper external debt to investigate sources of NFA, specifically that those variables seem to follow the same trend (Figure 3).

\section{ESTIMATION OF STERILIZATION AND OFFSET COEFFICIENT}

\subsection{Data Description}

All data used to estimate econometrically the $\triangle$ NDA (sterilization coefficient) and the $\Delta$ NFA (offset coefficient), in addition to all variables, are given monthly, from January 1994 to February $2011^{13}$. Our data was collected from IMF-IFS ${ }^{14}$ and from the Central Bank of each country and were seasonally adjusted. GDP was expressed by coincident indicator. Turkey and Lebanon data were respectively expressed in million local currencies and in billion local currencies $^{15}$, by converting monthly data on dollar-denominated into local currency terms using the average local currency price of the dollar for each month. We divided our study about Turkey into two periods: 1994-2000 and 2001-2010 separated by the financial crisis, in order to distinguished different trends of monetary aggregates and macreconomic variables, as represented by figures in the appendix. The NDA was defined by subtracting the NFA from the RM. Thus, a positive value of NFA corresponds to foreign inflows and a negative value of NDA indicates that the monetary authorities reduced their domestic assets held. The NFA was adjusted by taking the dollar denomination level of the FR and then adjusted them for the exchange rate changes; to give a valuation adjusted measure of changes in NFA in domestic currency. The formula of adjustment of the NFA is:

$\Delta N F A_{\text {Aadjusted }}=\left(F X_{t}\right) *\left(N F A^{16}{ }_{t}-N F A_{t-1}\right)-\left(F L_{t}-F L_{t-1}\right)$, where $\Delta$ is the change operator. FX is the average of monthly exchange rate of the local currency against the US Dollar and the $\mathrm{FL}^{17}$ is the Financial Liabilities of the Central Bank.

In the reaction function equation, the variables percentage change in GDP is always taken. Indeed, a simple version of the monetary approach to BP supposes that the increasing of NDA with the GDP growth rate, could meet growth in demand for money without resorting hoarding FR. The new in our study is that we took into consideration the effect of foreign liabilities (public debt expressed in foreign currencies) as an exogenous variable. In other

\footnotetext{
${ }^{13}$ For some economists like Christensen, 2004, using quarterly data would hide a lot of information on monthly movements because monetary policy reacts to fluctuations of the variables almost on a daily basis (exchange rate, liquidity movement etc..) and the market quickly respond to monetary policy measures.

${ }^{14}$ International Monetary Fund- International Financial Statistics

${ }^{15}$ Turkish lira TKL is the local currency for Turkey, and Lebanese pound LBP is the local currency for Lebanon.

${ }^{16}$ The NFA correspond to the IMF line 11D

${ }^{17}$ Correspond to the IMF Line $16 \mathrm{c}$
} 
words, we will study the impact of the dependence of countries to foreign currencies due to debts and to local market demands, on the monetary policy decision and reaction. The Money Multiplier (MM) permits to explain how the policy action influences the money stock. Ever since the MM has been developed by Brunner (1961) and Brunner and Meltzer (1964) ${ }^{18}$, it has been used in empirical analyses of money stock control and the impact of monetary policy actions on other economic variables. The $\mathrm{MM}$ is calculated by dividing the total M2 to RM. This variable argues that the control of money supplies relies on the authorities being able to control the monetary base. It is considered in several studies as an indicator that has a great impact on creating or withdrawing RM. In a case of a high de facto ${ }^{19}$ dollarized economy such Turkey and Lebanon where: 1 - the saving account in Commercial Bank and credit are expressed in foreign currency more that in local currency ${ }^{20}$ "financial dollarization", 2- where foreign currency in circulation also know as currency in hand are used as a medium of exchange "substitute money" in addition to 3 - the price of goods and service and/or salary in foreign currency "real dollarization"; the definition of Broad Money should be modified and corrected by the Effective Broad Money (Feige, 2003). Therefore, in our calculation, we considered first the Broad Money (MM); and then we used the Effective Broad Money (MMY), which consists of including the Foreign Currency in Circulation ${ }^{21}$ to see if there is any difference in results. The Interest rate "ITR" is used in our function as an exogenous variable to measure the difference between the deposit interest rate (6 month) on foreign currency and the deposit interest rate (6 month) on local currency. This variable has been chosen as a regulated instrument because of its important role in dollarized countries where US Dollar demand is high the domestic ITR should be more attractive than the external one; therefore the domestic ITR is strictly constrained by authorities to compete US Dollar ITR. The variation of gross external debt is added as exogenous variable. In fact, as described by the "snowball effect", the higher the interest rate (domestic) is, the more the charges for government will be heavy therefore, debt will increase to finance old debt with high interest rate if GDP is not sufficient and lower than the reel interest rate. Thus, if the CB stays away from money creation or is not allowed to create money, in order to avoid eventual high inflation, its last resort will be to increase the foreign debt.

\footnotetext{
${ }^{18}$ In the official site of the central Bank of Turkey : http://www.tcmb.gov.tr/yeni/eng/

19 The de jure or official dollarization economy consist of leaving completely the domestic currency and replacing it by a foreign currency.

${ }^{20}$ The ratio foreign currency deposit / total deposit $>30 \%$

${ }^{21}$ In the sum of M2, we should ad the M2Y witch takes into consideration all foreign currency deposit (including accounts) of residents (real sector entities).
} 
Variables used in the capital-flow functions to interpret the offset coefficient are known as control variables because of their role of motivating the capital inflow to the country. Montiel and Reinhart (1999) ${ }^{22}$ described the capital-flow function and called control variables incorporating as push versus pull ${ }^{23}$. Referring to his studies, we included as exogenous variables, the percentage change in GDP because, theoretically, the GDP growth influences on money. We also included the MM and MMY (Broad Money, and Effective Broad Money in two steps as explained above) because we considered that facing excessive monetary expansion will push down the interest rate and the $\mathrm{CB}$ will respond by using the foreign exchange market (i.e change in the NFA) while at the same time changing the monetary policy instruments (i.e changing in NDA). In this paper, we emphasized on the debts in general as a control variable, and external foreign debt particularly. The debt and more precisely, the foreign liabilities were included in our capital flow function, because: Firstly, increasing in debt may spur additional capital inflows directly (in the foreign market) and indirectly (if the government is financed by domestic banks that raise the necessary funds aboard). Secondly, the BP deficit of Lebanon and Turkey may results in a contraction of bank reserves by an identical amount. We used to add the percentage change of the local currency against the US dollar (FX) because FX reflects the central bank's exchange rate policy, especially in a country where the $\mathrm{CB}$ relies on foreign exchange intervention to maintain the exchange rate stability. In fact, a volatility of exchange rate may increase investment risk and uncertainty for foreign investors, hence diminishing the extent of capital inflows.

Based on the explanation above (part 2-3) consisting on decomposing the NFA, in addition to the Current account and the capital account, we included the external debt for two reasons: First, because the BP of representative countries is deficit, and literature talk about borrowing external debt as the only alternative for accumulating NFA. Second, because the trends of hoarding foreign reserves and the foreign liabilities seems to be similar (Figure 3 and Figure 4). In Lebanon, the important positive $\Delta$ NFA (in 1995, 20001, 2002, and 2008) corresponds to the dates of new engagement in foreign currencies. In Turkey too, the high positive $\triangle \mathrm{NFA}$ corresponds to new engagement of external debt (66 Billion US Dollar in 1996 and 100 billion US dollar in 1999). In addition, since the Transition of the String Economy Program TSEP supported by the IMF and the World Bank in 2001 consisting of reducing the ratio of domestic debt/GDP and external debt/GDP, we can see that $\triangle$ GED has decreased.

\footnotetext{
${ }^{22}$ Inn Ouyang and Rajan, 2005

${ }^{23}$ It consists in general of seven variables: 1- the M2, 2- the inflation, 3- the exchange rate, 4- the high lagged real output, 5the high government expenditure, 6- the high exchange rate adjusted in the interest rate and 7-the high volatility of exchange rate.
} 


\subsection{MODEL}

We implemented the Augmented Dickey-Fuller Test to check for unit roots, and we found that all variables used are stationary (Table 1).

Variables studied express the percentage change from log-first difference except for the ITR witch measure only the change. NDA and NFA are divided on RM lagged on the year before, because changes in the RM usually lead to increase or decrease in money credit that are larger than the changes in the $\mathrm{RM}^{24}$

\section{a- The Sterilization Function:} $\Delta N D A_{t} / R M-_{l}=\alpha+\beta \Delta N F A_{t} / R M_{-1}+\gamma \Delta \ln G D P_{t}+\delta \Delta \ln M M Y_{t}+\lambda \Delta I T R_{t}+\Phi \Delta \ln G E D_{t}+\varepsilon_{i}$ $\Delta N D A_{t} / R M_{-1}=\alpha+\beta \Delta N F A_{t} / R M_{-1}+\gamma \Delta \ln G D P_{t}+\delta \Delta \ln M M_{t}+\varepsilon_{i}$ (basic model)

The coefficient $\beta$ is the sterilization coefficient.

\section{b- The Capital-Flow Equation:}

$\Delta N F A_{t} / R M_{-1}=\alpha^{\prime}+\beta{ }^{\prime} \Delta N D A_{t} / R_{4}+\gamma^{\prime} \Delta \ln G D P_{t}+\delta^{\prime} \Delta \operatorname{lnMMY} Y_{t}+\lambda{ }^{\prime} \Delta \ln G E D_{t}+\Delta \ln F X_{t}+\varepsilon_{i}^{\prime}$ $\Delta N F A_{t} / R M_{-I}=\alpha^{\prime}+\beta{ }^{\prime} \Delta N D A_{t} / R M_{4}+\gamma^{\prime} \Delta \ln G D P_{t}+\delta{ }^{\prime} \Delta \ln M M_{t}+\varepsilon_{i}^{\prime}$ (basic model)

The coefficient $\beta$ ' is the offset coefficient.

Variables are expressed in log-first difference form and are used in Two Stage Least-Square (2LSLS) method. It is important to note that an endogeneity problem of the NFA variable in the sterilization function and of the NDA variable in the capital flow equation can bias all results ${ }^{25}$. Therefore, the Hausman endogeneity test has been carried out in order to check this problem of endogeneity. The endogeneity test of the table 2, which consists of adding the residual value of the sterilization function (capital flow equation) to the Capital flow function (sterilization function), indicated that the OLS was not consistent for Turkey due to the significant coefficient of the residual. Thus the 2SL2 method should be used. Although the Hausman test doesn't indicates the inconsistency of the OLS for Lebanon equations, due to theoretical implications and being in line with Obsfeld (1982), we would apply the 2SLS method for the estimation of equations for both countries.

The theory does not precisely say which instrument should be used in the models analyzed here, but econometrically, the instrument should be correlated with explanatory endogenous

\footnotetext{
${ }^{24}$ As seen in Aizenman and Glick (2008), and in Cavoli and Rajan (2005), Micossi and Rinaldi (1988). NDA and NFA were scaled by RM from the previous period in order to exclude the increase in their nominal variance series over time. ${ }^{25}$ In fact, Ouyang, Rajan and Willet 2007 works on seeking to control for the possible endogeneity of the explanatory variables on sterilization regressions through instrument estimation, and they didn't find much effect on coefficient magnitudes and their standard errors, as compared to OLS. Inn Aizenman et al 2008.
} 
variable and uncorrelated with the residuals from estimated model. The change on the exchange rate of the local currency against the US dollar was chosen as the instrumental variable in the sterilization function because, economically, the exchange rate is the nominal anchor of monetary policy in Turkey and the Central Bank maintains the stability of the exchange rate almost entirely through foreign exchange interventions, which will have impact on the change in the foreign exchange reserve of the central bank. Therefore, in the economic point of view, the change of FX is correlated with the movement of the NFA variable. As for the second equation, the change in the change in the Inflation rate INF was used as instrumental variable because; higher inflation could perpetuate concerns about exchange rate depreciation and interest rate hikes and capital losses, thereof, hence causing a reduction in capital inflows. Thus, NFA movement could be closely linked with the movement of NDA movement. Conditions of instrumental variables were accepted for Turkey.

As for Lebanon, due to its DE FACTO exchange rate regime since 1998, the choice of instrumental variables will vary. Based on the "Mundell trilemma" (inconsistent trinity), Desquibet (2007) explained that in Lebanon, the conventional fixed peg to a single currency imposes constraints to the monetary authority. In fact, when there is liberalization of capital, yields of different capital markets are determined by the markets forces and interest rate is realized selon conditions of non covered rate. Therefore, $\mathrm{CB}$ gives priority to the external stabilization (exchange rate, balance of payment) instead of the internal stabilization (domestic interest rate and domestic inflation), but as mentioned earlier, the variation of domestic interest rate should follow the modification of the US one.

Therefore, in an economic point of view, FX and CPI cannot be considered as instrumental variable in the equations as it is in the case of Turkey, and economitrically conditions required were not verified too. In contrast (other than the econometric reasons not correlating with the residual and correlating with the explanatory endogenious variable), we chose the variation of credit in foreign currency from Commercial Bank as instrumental variables for Lebanon. In fact, the deposit in foreign currency which is higher than the deposit in local currency (due to several reasons of dollarization cited above) is granted as credit to Lebanese agents. Knowing that Lebanese interest rate in US dollar is less than in Lebanese one, and that now salaries are more and more dispensed in local currency; these two latters increase the liquidity risk and solvability risk.

In order to avoid banking risk, $\mathrm{CB}$ intervene to limit credit in foreign currency to $70 \%$ of total foreign deposit, and encourage the deposit in domestic currency with the "Deposit Certificate" which consist of borrowing in foreign currency but reimbursing them in local 
currency. Therefore, the CB limits the credit in foreign currency with its intervention to the market and thus resulting in:

First, a direct impact in the change on the NFA in commercial bank, and so on in the CB: (instrumental variable in the first equation).

Second, interventions from CB in order to limit bank's lending to the private sector as well as to modify financing of the government. Since the NDA variable is as such to outline all changes in monetary policy instruments, NDA could be closely linked with the movement of credit bank: (instrumental variable in the second equation).

It should be noted that the equations have been tested for the presence of heterodasticity, using the white test, and for autocorrelation, using the Lagrange Multiplier test. In the equations that indicate the presence of heterodasticity and serial correlation of residuals ${ }^{26}$ variances have been corrected by using the method cohran-Orcutt $(\operatorname{ar}(1)$ or $\operatorname{ar}(2))$ and NeweyWest correction method.

\section{c-The Source of Foreign Reserve}

Considering that the $\triangle \mathrm{NFA}$ is equal to the variation of the BP account, therefore, the NFA can be divided into $\mathrm{CA}$ and $\mathrm{K}$ and scaled in lagged $\mathrm{RM}$ as following:

$\Delta N D A / R M_{-1}=\alpha+\beta_{1} C A / R M_{-1}+\delta_{1} K / R M_{-1}+\theta_{i} \Delta \ln G D P_{i}+\varepsilon_{i}$

The monthly data on dollar-denominated BP flows are converted into local currency terms using the average local currency price of the dollar for each month. We applied this equation for Turkey. However, in the case of Lebanon, due to a lack in the data concerning the CA and $\mathrm{K}$, we only used the variation of Trade Balance (TB) scaled on lagged RM of the year before. As seen in Aizenman and Glick (2008), the source of the FR is from the higher significant coefficient $\left(\beta_{1}\right.$ or $\left.\delta_{1}\right)$. In this article, we included the variation on gross external debt scaled by the lagged RM for the reasons explained above. Thus equations for Turkey and for Lebanon become:

$\Delta N D A / R M_{-1}=\alpha+\beta \Delta C A / R M_{-1}+\lambda_{1} \Delta K / R M_{-1}+\delta_{i} \Delta G E D / R M_{-1}+\theta_{i} \Delta l n G D P_{i}+\varepsilon_{i}$ $\Delta N D A / R M_{-1}=\alpha+\beta \Delta T B / R M_{-1}+\delta_{i} \Delta G E D / R M_{-1}+\theta_{i} \Delta \operatorname{lnGDP_{i}+\varepsilon _{i}}$

26 all equation in table 3 and 4, and equation 1 in table 5 and 6 


\section{RESULTS AND INTERPRETATION}

\subsection{Estimation of the Sterilization Coefficient}

The "basic model" in table 3 and 4, shows the results of the estimated sterilization coefficient and the offset coefficient in Turkey and Lebanon.

Sterilization coefficient in Turkey is -0.98; which means that Turkish Central Bank is doing a complete sterilization of capital inflow, and therefore every one unit of foreign exchange purchased by the $\mathrm{CB}$ is neutralized to reduce at the same amount the domestic assets, thus the reserve money becomes unchanged.

The offset coefficient in Turkey is $-0,93$. It is little lower than the sterilization coefficient, this result indicates that the CB's sterilization policy, (which is reflected in the reduction of NFA and withdrawal of RM through the reserve requirement instrument or open market operation), led only partially to additional capital inflows and ultimately to the increase in the central bank's NFA. The lower value of the offset coefficient compared to the sterilization coefficient indicates a certain degree of independence of monetary policy in neutralizing capital inflows.

As mentioned earlier, if the offset coefficient is -1 , this means that the sterilization's policy is totally ineffective. Whereas if the offset coefficient is equal to zero, this means that measures undertaken in the domestic market did not result in additional inflows.

In the case of Lebanon, the sterilization coefficient is equal to $-0,795$; which means that the Lebanese Central Bank does a partial sterilization of capital inflow, and therefore $79 \%$ of NFA are being used by the CB to reduce NDA.

The offset coefficient is equal to -0.864 and is little bit higher than sterilization-one. This is the worst case of offset, when it exceeds the sterilization coefficient. Knowing that the offset coefficient indicates the amount of the capital outflow per domestic currency of expansion of domestic credit, we deduce that the domestic and the foreign assets are close substitutes: 0,864 indicate a high degree of capital mobility and low degree of control over the money stock.

It is interesting to analyze the fact that the offset coefficient was higher than the sterilization coefficient. This means that with a low degree of control, the government is financing the trade balance deficit and the budget deficit by external foreign inflow (by borrowing). It was the case of Mexico in the 90s, where the Mexican government intervened in the economy by 
increasing external debt to finance current account and budget deficit. In fact, our period of studying (1994-2011) consist of a period of reconstruction of the Lebanese economy and an increase of the external debt going from $10 \%$ to more than $50 \%$ of total debt, and in absolute value, it was 5 times more (fgure 6). And every new engagemen (in 1995, 20001, 2002, and 2008) is followed by an increase in the $\triangle N F A$.

The GDP growth was positive and statistically significant in Turkey ( not for Lebanon); a stronger economic activity requires a large volume of money and transactions; thus monetary expansion.

MM was statistically significant for both countries as expected. The negative sign indicates that the higher MM is, the more the $\mathrm{CB}$ will reduce its NDA so that to respect the counter inflationary objective of monetary policy.

In order to study the case of Turkey and Lebanon, taking into consideration their particular characteristics of high dollarization rate and external debt, we estimated the sterilization and offset coefficient in the equation 1 and 2 described in tables 5 and 6 . For Turkey, the study was divided into two periods: before and after the crisis from 1994 to 2000 and from 2001 to 2011 so results can reflects more precisions.

- Starting with the equation 1 of tables 5 and 6, the sterilization coefficient for Turkey was $-1,01$ and -1.06 in the two periods. As explained above, Turkey is practicing a fully sterilization of Foreign Reserves. Lebanon too is almost practicing a fully sterilization with its coefficient equal to -0.96 .

As for exogenous variables, we found that MMY (M2 including foreign currencies) was statistically significant in both countries and the coefficient became higher (the coefficient of MMY exceeds -1 , while it was around $-0,7$ and $-0,8$ ). Thus the important impact of dollarization rate on the monetary reaction functions.

Although the alomot same sterilization coefficient in Turkey during two periods, the MM decrease from -1.3 to -1.03 . CB of Turkey may express more stability after the crisis and becomes less concerned about inflationary objective, or more stable.

The ITR was statistically significant for Lebanon and for Tyrkey (period before 2001) and the negative sign indicates that the higher difference between deposit domestic interest rate and deposit foreign interest rate, which induce higher capital inflows, require stronger sterilization in the sense of reducing the central bank's NDA. It is not for Turkey for Turkey 
after crisis. In fact, as showed in figure7, the interest rate was very high, which reflects an important impact on the monetary policy, until 2001. In the second period, the interest rate was almost stable and varied in the same trend with external interest rate, which indicates less and less important impact of interest rate on the NDA of $\mathrm{CB}$, resulting with more stable situation in comparison with previous period.

The GED was statistically significant in both countries and has a positive sign. In fact, the higher the deficit of BP is, the higher will be the external debt covering it, and so neutralizing the increasing of NFA by reducing the NDA. For Turkey, after 2001, the coefficient of GED decreased from 0.309 to 0.136 . As cited before, this is the result of TSEP supported by the IMF and the World Bank in 2001 consisting of reducing the ratio of domestic debt/GDP and external debt/GDP of Turkey.

The variation of GDP is statistically significant and positive in Lebanon and Turkey. Knowing that the sterilization coefficient is near to "- 1 ", this indicates that the CB supplies liquidity to the economy by increasing its claims in response to greater economy activity.

- Concerning the result of the Capital flow function (Equation2) in tables 5 and 6 , we found that both, Turkey before crises and Lebanon have a high offset coefficient, almost equal to sterilization coefficient, resulting in less effective sterilization policy. Especially in Lebanon where the offset sterilization is very close to the sterilization coefficient, resulting in a very bad application of this monetary policy. What it remarkable is the sterilization coefficient of Turkey in the second, which decrease to -0.875 this indicates a better sterilization monetary policy. MMY is statistically significant in both countries with negative sign, which means that a rise of MMY might increase the domestic money and push the interest rate down, and consequently reducing the capital inflow from abroad. In Turkey, MMY and variation of DA has same trend, which is logical due to the economic relation between the MMY and the domestic Money under constrains of sustainable inflation. The GDP is statistically significant in Lebanon, and in the first period of Turkey, which means that the growth of the domestic economy is relatively strong to be accompanied by monetary expansion. FX is significant for both countries, and the negative sign indicates that the depreciation (appreciation) of the local currency against the US dollar, will force the CB to sell foreign exchange (purchase foreign exchange), i.e reduce (increase) its NFA, which means spending its international reserves. In turkey, after 2001, the FX coefficient is much less than in the first period going from -1.786 to -0.759 in absolute value. It indicates the less implication of the $\mathrm{CB}$ in the foreign 
market, and the more flexible of exchange rate regime. As showed in figure 8 , the exchange rate regime in Turkey before 2001 was following a unique trend and increasing due to depreciation of its domestic currency, but after 2001, the trend was almost a sowtooth reflecting in more liberalization of its foreign market. In Lebanon, the coefficient of FX is relatively extremely high equal to -2.4 which represent the high implication of the monetary authority in the Lebanese foreign Market. In fact, despite the De Jure floated exchange rate regime, Lebanon's exchange rate regime is De Facto pegged to US dollar. And since the thirs quarter of 1999, the exchange rate volatility in Lebanon is zero (figure 8). Therefore, the CB can't tolerate any fluctuation and intervenes severely in the financial market to avoid any eventual devaluation, especially that in a highly dollarized country, where local currency is untrusted, the minimum fluctuation of the FX will result in panic and sudden stop, and/or converting the local currency by foreign currency and thus increasing the probability of financial crisis.

The positive sign of significant GED variables indicates that the monetary policy was countercyclical under the condition of growing general government debt. In fact, during the period of deficit financed by the government borrowing, the $\mathrm{CB}$ was accumulating foreign exchange reserves and neutralizing capital inflows by increasing net NFA, which provided leeway for reacting under the conditions of slower economic growth and limited inflow of capital abroad. The GED coefficient becomes smaller in Turkey in pre-crisis period which report the less increase of GED/GDP, as explained above.

Briefly, our results showed that for Turkey in the pre-crisis period and for Lebanon, every "one" unit of foreign reserved sterilized is offset. Sterilization policy becomes totally not effective or very weak. But starting from 2001, the sterilization monetary policy becomes more effective due to its lower value of the offset sterilization. There is a discrepancy between our results about Turkey and those seen in the studies by Altinkemer (1998), Celasun et al (1999) and Emir et al (2000), who studied the period prior to 1993. However, our results compares well with those found by Emir et al pertaining on the period between 1993 - 2000. As for Lebanon, there is no previous detailed study about sterilization monetary policy. Nevertheless, in several IMF reports about Lebanon's economy, it was mentioned that Lebanon should stop/reduce practicing the sterilization; which have substantially weakened the CB's net income position especially with its unsustainable cost. 


\subsection{Sources of NFA}

Does the sterilization responses to reserve inflows vary according to the source of the inflow?

Does the extent to which the central bank manages its domestic asset holding depend on whether reserve inflows are associated with BP and its components or the external debt?

These were questions asked by Aizenman and Glick (2008) about Asian and Latin America Emerging Countries, and have found that when the capital account was deficit, the inflows source was from the current account and vice versa, which is expected. Tables 6 and 7 show that in Turkey, only CA is statistically significant. This latter indicates that CA is the principal source of foreign outflow. In fact, as it was for many EMC countries, not all accounts in the BP were necessarily in excess. As for Lebanon, the TB account was not statistically significant. In fact, in figure 5 shows that despite the deficit of BP for both countries, Turkey's situation is much better that Lebanon's, and the deficit is remarkably lower, which may explain the non significance of TB. We should also indicate that replacing CA and K by TB in the case of Lebanon weakens the estimation and the conclusion, and can only give a general idea about the significance of the TB account. In other words, the more the TP is decomposed into several accounts, the more the source of NFA is precise... However, variation of the GED/RM-1 was statistically significant for both countries, which confirms the close link between the growth external debt and the foreign outflow. The positive sign explain the opposite trajectory with the foreign outflow, in another way, when the BP is deficit, borrowing foreign increase in order to fill the gap thus the opposite sign of the variable. The higher coefficient in the second period in Turkey consist o the increasing of the deficit (figure 5) in TB, filled by the external debt. We have seen the GED/GDP in Turkey was decreasing, thus, sterilization and offset coefficient were smaller. But in this case, the coefficient becomes bigger in the period pre-crisis, which reflects the need of GED relatively to the increase of the Turkish deficit.

As seen in tables 6 and 7, Adjusted R-Squared is small especially for Lebanon. The model misses many explicative variables, but lead to give only about the impact off the BP on the sterilization monetary policy. 


\section{IMPORTANT REMARKS}

1- It should be noted that the sterilization coefficient and the offset coefficient are parameters determining only the stance of monetary policy but not the fully understanding of monetary policy $^{27}$. If we limited the definition of sterilization's efficiency to Disyatat and Galati (2005), we would only interpret the efficiency of the foreign exchange interventions (i.e. conversion in capital inflows) by using the basic model, which measures the extent to which they have been sterilized (i.e. quantifying their impact on RM only). But efficiency of sterilization and especially the efficiency of the foreign intervention depend on many other macroeconomic and financial variables and market conditions.

2- IR and Sterilization studies are always completed with the cost of sterilization to estimate whether it is successful or not (in term of trade-of between control over bank reserves and control over foreign exchange reserves implicit in the choice among sterilization policies) and/or whether it is long term or short term sustainable or not. Sterilization cost based on interest rate studies will be treated in a paper separately.

\footnotetext{
${ }^{27}$ Requires information about changes in private and public Banks's reserve requirement, discount window, etc.
} 


\section{Conclusion}

Our paper investigates the sterilization monetary policy in Turkey and Lebanon, who theatrically enjoyed from the application of the sterilization policy, but in return, are suffering from economic constrains such deficit in Balance of Payment, high external debt and important dollarization rate, which in theory should decrease the efficiency of the sterilization monetary policy.. We found that every unit of Net Domestic Asset (NDA) decreased by the Central Bank (CB) for Turkey and Lebanon from the sterilization policy is almost replaced by additional unit of foreign exchange inflows and contributes to increase or the Net Foreign Asset (NFA). This additional unit inflows needs to be sterilized again, which creates a vicious circle of rising capital inflows and the need for additional sterilization resulting of less effective policy. However, for Turkey, after the financial crisis from 2001, the offset coefficient decreased, resulting in a better application of sterilization policy. In addition when decomposing the NFR into Balance of Payment accounts in order to measure its impact on the variation of NDA, we found a week relation in opposite of previous results, which in theory should be similar. However we found a significant positive relation between the gross external debt and the decreasing of the NDA, which confirm the "debt divert" to fill the BP deficit. We conclude that despite their theoretical practice of sterilization policy in Turkey and Lebanon, economic constrains of these countries contribute to weaken the efficacy expected from monetary policies.

Lebanon and Turkey, which suffered from a high dollarization rate, and a deficit BP, increase the IR (Dominguez 2009) by borrowing reserves after being depleted. This will on one side, increase the external debt (Obsfend et al 2009), and on the other side, if IR is sterilized, it will prompt rises in domestic debt by monetizing it (Calvo 1990). The latter is as serious and as dangerous as the external debt (Calvo 2006), it represents the key barriers to economic progress and weeakens the central bank role. We conclude that country which basically suffers from economic constraints; sterilization of IR becomes a source of macroeconomic vulnerability. 


\section{REFERENCES}

Aizenman J, Jinjarak Y, Park D, 2011, International Reserves ans Swap Lines: Substitutes or Complements?; International Review of Economics and Financel, 20(1)

Aizenman J, Lee J W, 2010, Hoarding International Reserves Versus a Pigovian Tax-CumbSubsidy Scheme; USCS and NBER Working Paper, $N^{\circ} 15484$

Aizenman J, 2009; Financial Crisis and the Paradox of Under -and-Over Regulation; NBER Working Paper $N^{\circ} 15018$

Aizenman J, Chinn M.D, Ito H, 2008. Assessing the Trilemma Global Financial Architecture: Measuring the Trilemma's Configuration over Time. NBER Working Paper $N^{\circ}$ 14533

Aizenman J, Lee J W; 2008; Financial versus Monetary Mercantilism-Long Run View of Large International Reserves Hoarding; Wolrd Economy $N^{\circ} 31$

Aizenman J, Marion N ; 2004; International Reserves Holdings with Sovereign risk and costly tax collection, Economic Journal 114, pp 569-91

Altinekemer M, 1998, Capital Inflows and Central Bank's Policy Response, The Central Bank of the Republic of Turkey and costly tax collection” Economic Journal 114

Caballero R J, Krishnamurthy A; 2001; International Liquidity Illusion: On the Risk of Sterilization; NBER Working Paper, $N^{\circ} 8141$

Calvo G; 1990 ; The peril of sterilization, IMF Working Paper $N^{\circ}$ 90/13

Calvo G, Reinhart C, 1999, Capital Flow Reversals, The exchange Rate Debate and Dollarization, Finance and developpement, A Quarerly Magazine of IMF

Calvo G, Reinhart C; 2002: Fear of Floating, The Quarterly Journal of Economics, VolCXVII; Issue 2.

Calvo G, 2006; Monetary Policy Challenges in Emerging Markets: Sudden Stop, Liability Dollarization, and Lender of Last Resort, NBER Working Paper $N^{\circ} 12788$

Cavoli T ; Rajan R S ; 2005 ; The Central Inflow Problem in Selected Asian Economies in the 1990s Revisited : The Role of Monetary Sterilization; Singapore Centre for Applied and Policy Economics, Paper $N^{\circ} 2005 / 18$

Celasun O, Denize D, He D, 1999; Capital Flows, Macroeconomic Management and Financial System, Turkey-1997, World Bank 
Christensen J, 2004 ; Capital Inflows, Sterilization, and Commercial Bank Speculation : The case of the Czech Republic in the Mid-1990s, IMF, Paper $N^{\circ}$ wp/04/218

Cumby R E, Obsfeld M, 1982 : Capital Mobility and the Scope for Sterilization : Mexico in the 1970s, NBER, Paper $N^{\circ} 770$

Desquilbet Jean-Batiste, 2007, Les contraintes de la politique monétaire libanaise (19932004): endettement public, dollarization et taux de change fixe ; L'Actualité économique, Revue d'Analyse économique, vol.83, $n^{\circ} 2$, pp.163-199

Disyatat, P. et G. Galati, 2005 , The effectiveness of foreign exchange intervention in emerging market economies », BIS Papers, $n^{\circ} 24$, mai, pp. 97-113

Dominguez K, ME, 2009, International reserves and Underdeveloped Capital Market, Univesity of Michigan and NBER, $N^{\circ} 600$

Eichengreen B, Hausmann R; 1999; Exchange Rate and Financial Fragility; NBER Working Paper $N^{\circ} 7418$

Emir O Y, Karasoy A, Kunter K, 2000 : Sterilization Function in Turkey; Central Bank of the Republic of Turkey

Feige L E, 2003, Dynamic of Currency Substitution, Asset Substitution and de facto Dollarisation and Euroisation in Transition Countries; Comparative Economic Studies, $N^{\circ} 45$, p.358-383

Fischer, Stanley, 2001; Exchange Rate Regime: Is the Bipolar View Correct?; The Journal of Economic Perspectives $N^{\circ} 15$

Frankel J A, 1997, Sterilization of Money Inflows: Difficult (Calvo) or easy (Reisen)?, Estudios de Economia, vol 24; issue 2.

Herring J R, Marston C R, 1977; Sterilization policy: The Trade-Off between Monetary Autonomy and International Reserve Stability; Rodney L. White Center For Financial Research, Working Paper $N^{\circ} 19-77$

Jeanne O, Rancière R; 2009; The Optimal Level of International Reserves for Emerging Market Countries: Formulas and Applications, IMF and CEPR, $N$

Kouri P, Porter R, 1974; International Capital Flows and Portfolio Equilibrium, Journal of Political Economy, Vol 82, pp.443-467 
Obsfeld M, Schaumbaugh J C, Taylor A M, 2009, Financial Instability, Reserves, and Central Bank Swap Lines in the Panic of 2008, NBER Working Paper, $N^{\circ} 14826$

Obsfeld M, Schambaugh J C, Taylor A M, 2004; Monetary Sovereignty, Exchange Rates and Capital Controls: The Trilemma in the Interwar Period, NBER Working Paper, $N^{\circ} 10393$ Obsfeld M, 1982; Sterilization and the Offsetting Capital Movement Evidence from West Germany, 1960-1970, NBER, paper $N^{\circ} 0494$

Ouyang A Y, Rajan R S, 2005, Monetary Sterilization in China Since the 1990s: How Much and How Effective? Centre of International Economic University, paper Studies, $N^{\circ} 0507$ 


\section{APPENDIX}

Table 1: Dickey Fuller Test

\begin{tabular}{|c|c|c|c|}
\hline Variables & Description of variable & $\begin{array}{l}\text { TURKEY } \\
\text { T-Statistic }\end{array}$ & $\frac{\text { LEBANON }}{\text { T-Statistic }}$ \\
\hline$\Delta$ NFA/RM-1 $_{-1}$ & $\left(\mathrm{NFA}_{\mathrm{t} 2}-\mathrm{NFA}_{\mathrm{t} 1}\right) / \mathrm{RM}_{-1}$ & $-6,46 * * *$ & $-14,18 * * *$ \\
\hline$\Delta \mathrm{NDA}_{\mathbf{R}} \mathbf{R M}_{-1}$ & $\left(\mathrm{NDA}_{\mathrm{t} 2}-\mathrm{NDA}_{\mathrm{t} 1}\right) / \mathrm{RM}_{-1}$ & $-6,336 * * *$ & $-14,20 * * *$ \\
\hline$\Delta \ln G D P$ & $\operatorname{lnGDP}_{\mathrm{t}^{-}} \ln \mathrm{GDP}_{\mathrm{t} 1}$ & $-7,695 * * *$ & $-10,82 * *$ \\
\hline$\Delta I T R$ & $\left(\mathrm{INT}_{\mathrm{fx}_{\mathrm{x}}}-\mathrm{INT}_{\mathrm{dom}}\right)_{\mathrm{t} 2^{-}}\left(\mathrm{INT}_{\mathrm{fx}}-\mathrm{INT}_{\mathrm{dom}}\right)_{\mathrm{t} 1}$ & $-8,18 * * *$ & $-9,75^{* * *}$ \\
\hline$\Delta \operatorname{lnMMY}$ & $\ln M M Y_{t 2^{-}} \ln M M Y_{t 1}$ & $-17,184 * * *$ & $-6,936 * * *$ \\
\hline$\Delta \ln M M$ & $\ln M_{\mathrm{t}^{-}} \ln \mathrm{MM}_{\mathrm{t} 1}$ & $-14,08 * * *$ & $-15,008 * * *$ \\
\hline$\Delta \operatorname{lnGED}$ & $\operatorname{lnGED}_{\mathrm{t}^{-}}-\operatorname{lnGED} \mathrm{t}_{\mathrm{t}}$ & $-10,884 *$ & $-15,54 * *$ \\
\hline$\Delta$ GED/RM-1 $_{-1}$ & $\left(\mathrm{GED}_{\mathrm{t} 2^{-}}-\mathrm{GED}_{\mathrm{t} 1}\right) / \mathrm{RM}_{-1}$ & $-13,83^{*}$ & $-21,9 * * *$ \\
\hline$\Delta \mathrm{EXPORT} / \mathrm{RM}_{-1}$ & $\left(\mathrm{EXPORT}_{\mathrm{t} 2}-\mathrm{EXPORT}_{\mathrm{t} 1}\right) / \mathrm{RM}_{-1}$ & ------- & $-21,9 * * *$ \\
\hline$\Delta \mathrm{K} / \mathbf{R M}_{-1}$ & $\left(\mathrm{~K}_{\mathrm{t} 2}-\mathrm{K}_{\mathrm{t} 1}\right) / \mathrm{RM}_{-1}$ & $-7,25 * * *$ & $\begin{array}{c}---- \\
\end{array}$ \\
\hline$\Delta \mathrm{CA} / \mathbf{R M}_{-1}$ & $\left(\mathrm{CA}_{\mathrm{t} 2^{-}} \mathrm{CA}_{\mathrm{t} 1}\right) / \mathrm{RM}_{-1}$ & $-4,28 * * *$ & $\begin{array}{ll}---- \\
\end{array}$ \\
\hline$\Delta \mathbf{F X}$ & $\operatorname{lnFX} \mathrm{t}_{2}-\ln F X_{\mathrm{t} 1}$ & $-10,606 * * *$ & $-2,92 * * *$ \\
\hline INF & $\operatorname{lnCPI}{ }_{t 2}-\ln \mathrm{CPI}_{\mathrm{t} 1}$ & $-14,67 * * *$ & --------- \\
\hline Residual-1 & equation 1 & $-12,03 * * *$ & $-11,26 * * *$ \\
\hline Residual-2 & equation 2 & $-3,462 * * * *$ & $-9,19 * * *$ \\
\hline Residual-3 & equation 3 & $-5,66^{* * *}$ & $-7,33 * * *$ \\
\hline Residual-4 & equation 4 & $-10,85 * * *$ & $-6,98 * * *$ \\
\hline Residual-5 & Equation 5 (source of NFA) & $-13,31 * * *$ & $-13,86 * * *$ \\
\hline
\end{tabular}

*Significant at $10 \%, * *$ significant at $5 \%$, ***significant at $1 \%$ 
Table 2

Hausmann Test for endogeneity

A-Lebanon:

Sterilization coefficient: equation 1

Dependent Variable: $\triangle \mathrm{NDA} / \mathrm{RM}_{-1}$

Method: Least Squares: OLS

Included observations: 194 after adjustment: 1995M01-

2011M02

\begin{tabular}{lcc}
\hline \hline Variable & Coefficient & Prob. \\
\hline \hline $\mathrm{C}$ & 0.011120 & 0.0000 \\
$\Delta \mathrm{NFA}_{\mathrm{R}} \mathrm{R}_{-1}$ & -0.921339 & 0.0000 \\
$\Delta \mathrm{lnGDP}$ & 0.052648 & 0.0277 \\
$\Delta \mathrm{lnMMY}$ & -1.162505 & 0.0000 \\
$\Delta \mathrm{ITR}$ & -0.006426 & 0.0385 \\
$\Delta \mathrm{lnGED}$ & 0.043094 & 0.0117 \\
Hausman_res & -0.045028 & 0.5032 \\
\hline \hline R-squared & 0.945881 & \\
Adjusted R-squared & 0.943822 & \\
\hline \hline
\end{tabular}

Offset coefficient : equation 2

Dependent Variable: $\triangle \mathrm{NFA} / \mathrm{RM}_{-1}$

Method: Least Squares : OLS

Included observations: : 192 after adjustment: 1995M03 2011M02

\begin{tabular}{lrl}
\hline \hline Variable & Coefficient & Prob. \\
\hline \hline $\mathrm{C}$ & 0.010695 & 0.0000 \\
$\Delta \mathrm{NDA}_{\mathrm{R}} \mathrm{RM}_{-1}$ & -0.938852 & 0.0000 \\
$\Delta \operatorname{lnGDP}$ & 0.046381 & 0.0376 \\
$\Delta \operatorname{lnMMY}$ & -1.090796 & 0.0000 \\
$\Delta \operatorname{lnGED}$ & 0.056286 & 0.0032 \\
$\Delta \operatorname{lnFX}$ & -2.390356 & 0.0017 \\
Hausman_res & 0.010178 & 0.8516 \\
\hline \hline & & \\
R-squared & 0.927163 & \\
Adjusted R-squared & 0.923979 & \\
\hline \hline
\end{tabular}




\section{B-Turkey}

Sterilization coefficient: equation 1

Dependent Variable: $\triangle \mathrm{NDA}_{\mathrm{R}} \mathrm{RM}_{-1}$

Method: Least Squares

Included observations: 204 after adjustments : 1994M01 2010M12

\begin{tabular}{lrl}
\hline \hline Variable & Coefficient & Prob. \\
\hline \hline $\mathrm{C}$ & 0.005279 & 0.0000 \\
$\Delta \mathrm{NFA} / \mathrm{RM}_{-1}$ & -1.026897 & 0.0000 \\
$\Delta \operatorname{lnPIB}$ & 0.028382 & 0.8936 \\
$\Delta \operatorname{lnMMY}$ & -1.093064 & 0.0000 \\
$\Delta \operatorname{lnGED}$ & 0.233129 & 0.4636 \\
INTERET & -0.000792 & 0.0786 \\
Hausman_res & 0.005755 & 0.9746 \\
\hline \hline R-squared & 0.980617 & \\
Adjusted R-squared & 0.979921 & \\
\hline \hline
\end{tabular}

Offset coefficient : equation 2

Dependent Variable: $\triangle \mathrm{NFA} / \mathrm{RM}_{-1}$ Method: Least Squares

Included observations: 202 after adjustments : 1994M02 2010M11

\begin{tabular}{lrl}
\hline \hline Variable & Coefficient & Prob. \\
\hline \hline $\mathrm{C}$ & 0.018449 & 0.0000 \\
$\Delta \mathrm{NDA} / \mathrm{RM}_{-1}$ & -0.720444 & 0.0000 \\
$\Delta \operatorname{lnPIB}$ & 0.546292 & 0.0009 \\
$\Delta \operatorname{lnMMY}$ & -1.027265 & 0.0000 \\
$\Delta \operatorname{lnGED}$ & 0.339640 & 0.1581 \\
$\Delta \operatorname{lnFX}$ & -0.264296 & 0.2672 \\
Hausman_res & -0.205187 & 0.0000 \\
\hline \hline R-squared & 0.978302 \\
Adjusted R-squared & 0.977403 \\
\hline \hline
\end{tabular}


Table 3

Basic Evaluation of sterilization monetary policy in Turkey

a- Sterilization coefficient (equation 1)

Dependent ariable $\triangle \mathrm{NDA} / \mathrm{RM}_{-1}$ Included observations: 205 after adjustments: 1994M022011M02

\begin{tabular}{lcl}
\hline \hline Variable & Coefficient & Prob. \\
\hline \hline $\mathrm{C}$ & 0.053544 & 0.0000 \\
$\Delta \mathrm{NFA} / \mathrm{RM}_{-1}$ & -0.982121 & 0.0000 \\
$\Delta \operatorname{lnPIB}$ & 0.105029 & 0.0818 \\
$\Delta \operatorname{lnMM}$ & -0.781161 & 0.0000 \\
\hline \hline R-squared & \multicolumn{2}{c}{0.955312} \\
Adjusted R-squared & 0.954418 \\
\hline \hline
\end{tabular}

Lagged dependent variable \& regressors added to instrument list

\section{b- Offset Coefficient (equation 2)}

Dependent Variable: $\triangle \mathrm{NFA} / \mathrm{RM}_{-1}$

Included observations: 202 after adjustments : 1994M02 2010M11

\begin{tabular}{lcc}
\hline \hline Variable & Coefficient & Prob. \\
\hline \hline $\mathrm{C}$ & 0.038295 & 0.0000 \\
$\Delta \mathrm{NDA} / \mathrm{RM}_{-1}$ & -0.938178 & 0.0000 \\
$\Delta \ln \mathrm{PIB}$ & 0.0776766 & 0.0701 \\
$\Delta \operatorname{lnMM}$ & -0.877852 & 0.0000 \\
\hline \hline
\end{tabular}

R-squared $\quad 0.956424$

Adjusted R-squared 0.955539

Lagged dependent variable \& regressors added to instrument list 
Table 4

Basic Evaluation of sterilization monetary policy in Lebanon

a- Sterilization coefficient (equation 1)

Dependent Variable: $\triangle \mathrm{NDA} \mathrm{RM}_{-1}$

Included observations: 205 after adjustments : 1994M02 2011M02

\begin{tabular}{lcc}
\hline \hline Variable & Coefficient & Prob. \\
\hline \hline $\mathrm{C}$ & 0.014052 & 0.0000 \\
$\Delta \mathrm{NFA}_{\mathrm{R}} \mathrm{RM}_{-1}$ & -0.795382 & 0.0000 \\
$\Delta \operatorname{lnGDP}$ & 0.064716 & 0.1201 \\
$\Delta \operatorname{lnMM}$ & -0.815449 & 0.0000 \\
\hline \hline R-squared & 0.802158 & \\
Adjusted R-squared & 0.799205 &
\end{tabular}

Lagged dependent variable \& regressors added to instrument list

b- Offsent coefficient (equation 2)

DependentVariable: $\triangle \mathrm{NFA} / \mathrm{RM}_{-1}$

Included observations: 205 after adjustments: 1994M02 2011M02

\begin{tabular}{lcl}
\hline \hline \multicolumn{1}{c}{ Variable } & Coefficient & Prob \\
\hline \hline $\mathrm{C}$ & 0.015749 & 0.0001 \\
$\Delta \mathrm{NDA}^{2} \mathrm{RM}_{-1}$ & -0.864253 & 0.0000 \\
$\Delta \operatorname{lnGDP}$ & 0.077433 & 0.0641 \\
$\Delta \operatorname{lnMM}$ & -0.685480 & 0.0004 \\
\hline \hline \multicolumn{1}{c}{ R-squared } & 0.727893 & \\
\multicolumn{1}{c}{ Adjusted R-squared } & 0.722451 & \\
\end{tabular}

Lagged dependent variable \& regressors added to instrument list 


\section{Table 5}

\section{Estimating the efficiency of the sterilization monetary policy in Turkey}

\section{Sterilization coefficient (equation 1)}

a-Dependant variable $\Delta \mathrm{NDA} / \mathrm{RM}_{-1} \mathrm{~b}$ Included observations: 83

From 1994M02 to 2000M12
Dependant variable $\Delta \mathrm{NDA} / \mathrm{RM}_{-1}$ Included observations: 120 From 2001M01 to 2010M12

\begin{tabular}{|c|c|c|c|c|c|}
\hline Variable & Coefficient & Prob & Variable & Coefficient & Prob. \\
\hline $\mathrm{C}$ & -1.019570 & 0.0000 & $\mathrm{C}$ & -1.062959 & 0.0000 \\
\hline$\Delta \mathrm{NFA} / \mathrm{RM}_{-1}$ & -1.019570 & 0.0000 & $\Delta \mathrm{NFA} / \mathrm{RM}_{-1}$ & -1.069455 & 0.0000 \\
\hline$\Delta \ln \mathrm{PIB}$ & 0.095623 & 0.6412 & $\Delta \ln \mathrm{PIB}$ & -0.104732 & 0.3284 \\
\hline$\Delta \ln M M Y$ & -1.311931 & 0.0000 & $\Delta \operatorname{lnMMY}$ & -1.033563 & 0.0000 \\
\hline$\Delta \operatorname{lnGED}$ & 0.309115 & 0.0138 & $\Delta \ln G E D$ & 0.1369933 & 0.0395 \\
\hline$\Delta \mathrm{INT}$ & -0.001235 & 0.0664 & $\triangle \mathrm{INT}$ & -0.001273 & 0.4702 \\
\hline R-squared & & R-squared & 0.985128 & \\
\hline Adjusted R- & \multicolumn{2}{|c|}{0.982753} & Adjusted R- & 0.984415 & \\
\hline \multicolumn{6}{|c|}{ Lagged dependent variable $\&$ regressors added to instrument list } \\
\hline
\end{tabular}

Offset coefficient (equation 2)

a-Dependant variable $\triangle \mathrm{NFA} / \mathrm{RM}_{-1}$ Included observations: 201 From 1994M03 to 2010M11
b-Dependant variable $\Delta \mathrm{NFA} / \mathrm{RM}_{-1}$ Included observations: 119

From 2000M01 to 2010M11

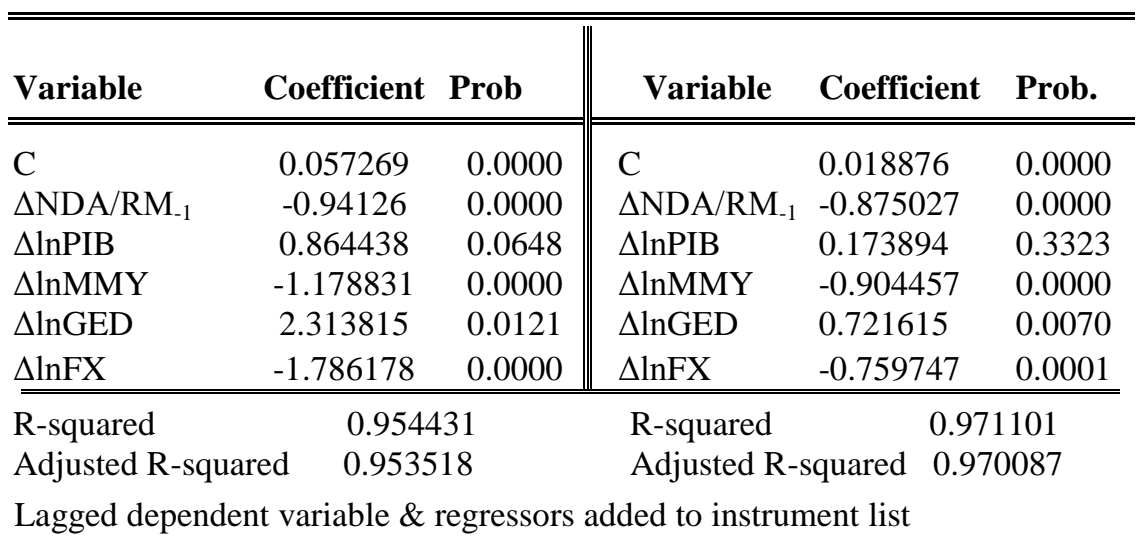


Table 6

Estimating the efficiency of the sterilization monetary policy in

Lebanon

a- Sterilization coefficient (equation 1)

Dependent Variable: $\triangle$ NDA/RM-1

Included observations: 193 after adjustments

\begin{tabular}{lcc}
\hline \hline $\mathrm{C}$ & 0.011739 & 0.0000 \\
$\Delta \mathrm{NFA} \mathrm{RM}_{-1}$ & -0.966249 & 0.0000 \\
$\Delta \operatorname{lnGDP}$ & 0.050334 & 0.0339 \\
$\Delta \operatorname{lnMMY}$ & -1.11 & 0.0000 \\
$\Delta \operatorname{lnGED}$ & 0.044470 & 0.0340 \\
$\Delta \mathrm{INT}$ & -0.006189 & 0.0470 \\
\hline \hline
\end{tabular}

R-squared $\quad 0.945749$

Adjusted R-squared $\quad 0.943989$

Lagged dependent variable \& regressors added to instrument list

b-Offset Coefficient (Equation 2)

Dependent Variable: $\triangle \mathrm{NFA} / \mathrm{RM}_{-1}$

Included observations: 193 after adjustments : 1995M02 2011M02

\begin{tabular}{lcc}
\hline \hline \multicolumn{1}{c}{ Variable } & Coefficient & Prob. \\
\hline \hline $\mathrm{C}$ & 0.011289 & 0.0000 \\
$\Delta \mathrm{NDA} / \mathrm{RM}_{-1}$ & -0.941206 & 0.0000 \\
$\Delta \operatorname{lnGDP}$ & 0.063945 & 0.0025 \\
$\Delta \operatorname{lnMMY}$ & -1.109674 & 0.0000 \\
$\Delta \operatorname{lnGED}$ & 0.035707 & 0.0288 \\
$\Delta \operatorname{lnFX}$ & -2.44217 & 0.0008 \\
\hline \hline R-squared & \multicolumn{2}{c}{0.940242} \\
Adjusted R-squared & 0.938422 \\
\hline \hline
\end{tabular}

Lagged dependent variable \& regressors added to instrument list 
Tables 7

\section{Sources of Foreign Reserves}

\section{a-Turkey}

Dependent Variable: $\triangle \mathrm{NDA} / \mathrm{RM}_{-1}$

Method: Least Squares

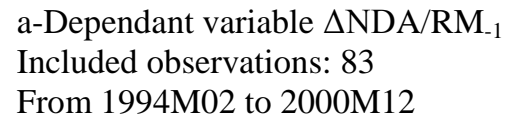

a-Dependant variable $\Delta \mathrm{NDA} / \mathrm{RM}_{-1}$ Included observations: 83

From 1994M02 to 2000M12

b-Dependant variable $\Delta \mathrm{NDA} / \mathrm{RM}_{-1}$ Included observations: 120

From 2001M01 to 2010M12

\begin{tabular}{|c|c|c|c|c|c|}
\hline Variable & Coefficient & Prob. & & $\begin{array}{l}\text { Variabl } \\
\mathrm{e}\end{array}$ & Coefficient Prob. \\
\hline $\mathrm{C}$ & 0.028605 & 0.2269 & C & 0.002151 & 0.9926 \\
\hline$\Delta \ln P I B$ & 1.814493 & 0.0056 & $\Delta \ln P I B$ & 0.824710 & 0.0526 \\
\hline$\Delta \mathrm{CA} / \mathrm{RM}_{-1}$ & -0.458583 & 0.0552 & $\Delta \mathrm{CA} / \mathrm{RM}_{-1}$ & -0.186437 & 0.05232 \\
\hline$\Delta \mathrm{K} / \mathrm{RM}_{-1}$ & 0.084247 & 0.2892 & $\Delta \mathrm{K} / \mathrm{RM}_{-1}$ & 0.131557 & 0.1854 \\
\hline$\Delta \mathrm{GED} / \mathrm{RM}_{-1}$ & 0.181869 & 0.0000 & $\Delta \mathrm{GED} / \mathrm{RM}_{-1}$ & 0.335801 & 0.0000 \\
\hline R-squared & 0.514334 & & \multicolumn{2}{|c|}{ R-squared } & 0.514334 \\
\hline Adjusted R-squared & 0.489744 & & \multicolumn{2}{|c|}{ Adjusted R-squared } & 0.489744 \\
\hline
\end{tabular}

\section{b-Lebanon}

Method: Least Squares

Dependent Variable: $\triangle \mathrm{NDA} / \mathrm{RM}_{-1}$

Included observations: 205 after adjustments : 1994M02- 2011M02

\begin{tabular}{lrc}
\hline \hline Variable & Coefficient & Prob. \\
\hline \hline $\mathrm{C}$ & -0.26241 & 0.0787 \\
$\Delta \ln T B / R_{-1}$ & -0.062133 & 0.0351 \\
$\Delta$ GED/RM & 0.037102 & 0.0181 \\
$\Delta \operatorname{lnGDP}$ & -0.067167 & $0.4983 \mathrm{NS}$ \\
\hline \hline R-squared & 0.174625 & \\
Adjusted R-squared & 0.158709 & \\
\hline \hline
\end{tabular}




\section{APPENDIX}

Figure 1-

Foreign Reserve on GDP

a-World from 1980 to 2006

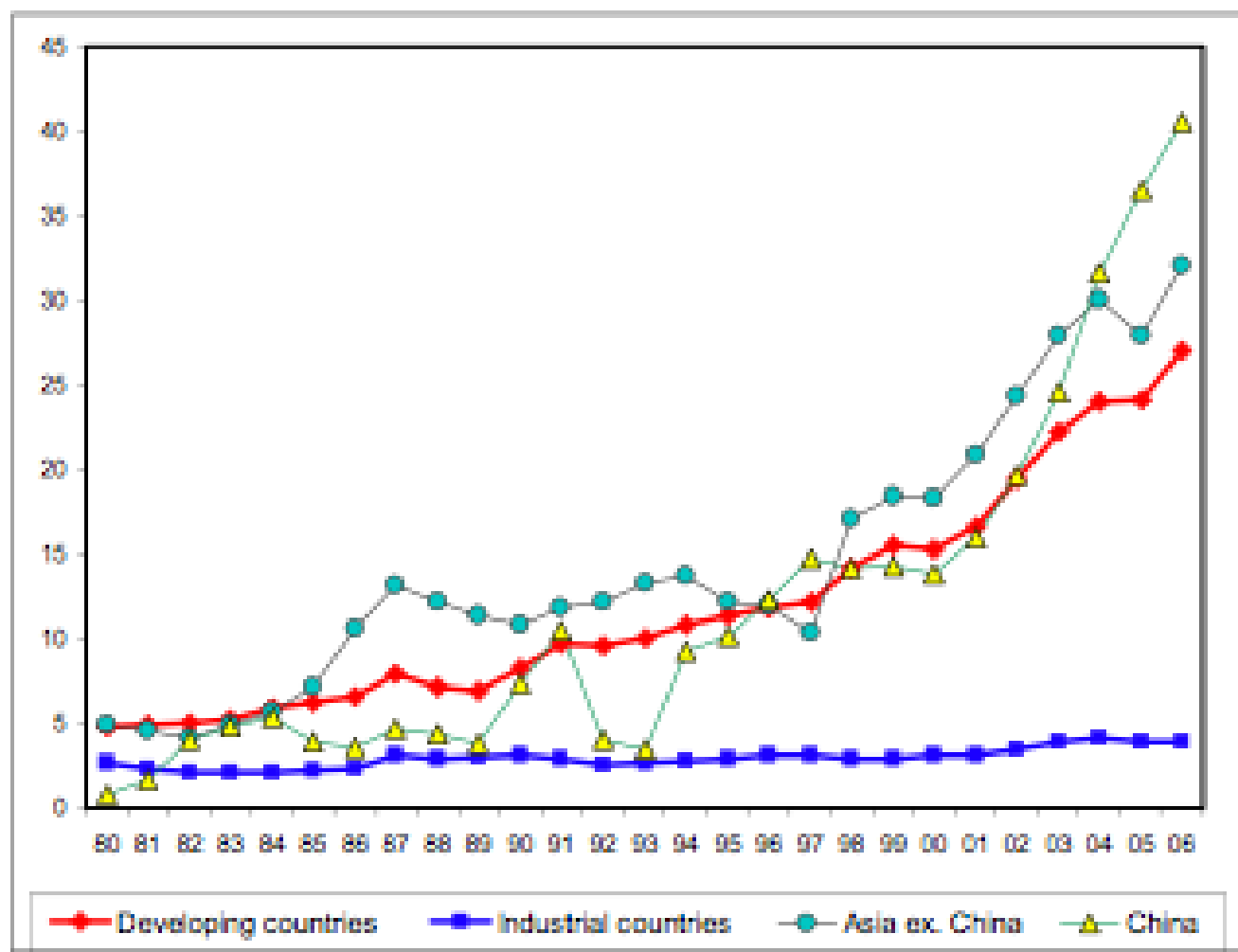

Source : Aizenman, Chinn, Ito, 2008 
Figure 2

Variation of NDA/RM and NFA/RM

Latin America Countries and East Asia (Source : Aizenman, Chinn, Ito, 2008)

ARGENTINA

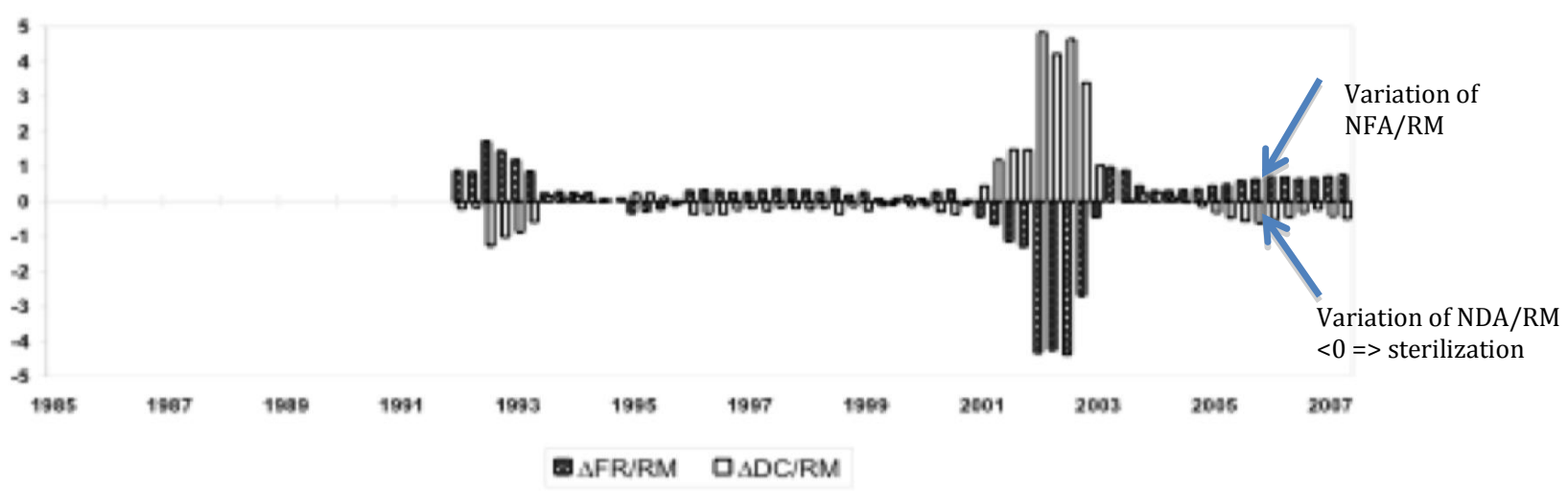

BRAZIL
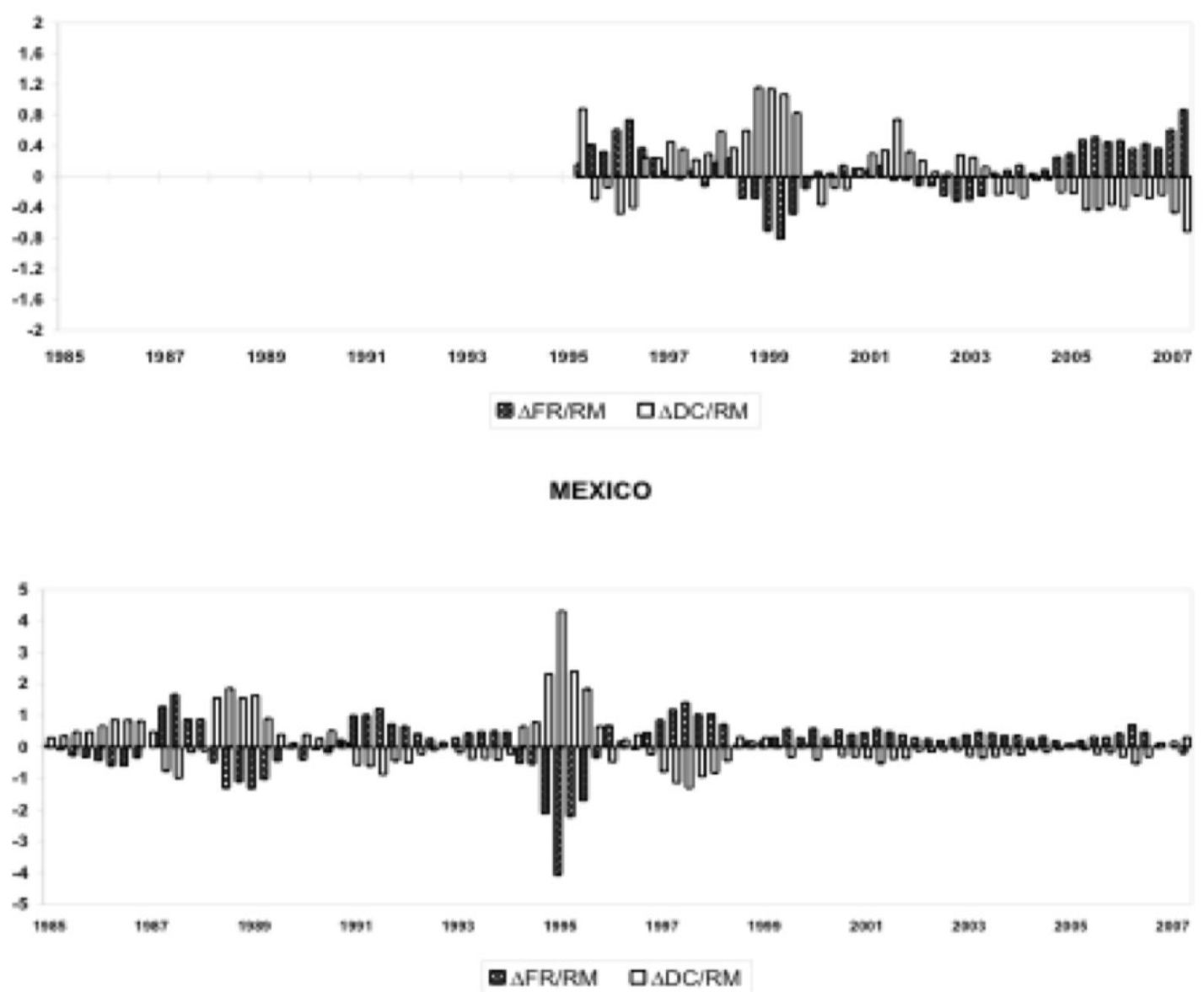

Note: positive values correspond to foreign reserve inflows or domestic asset increases. 
CHINA
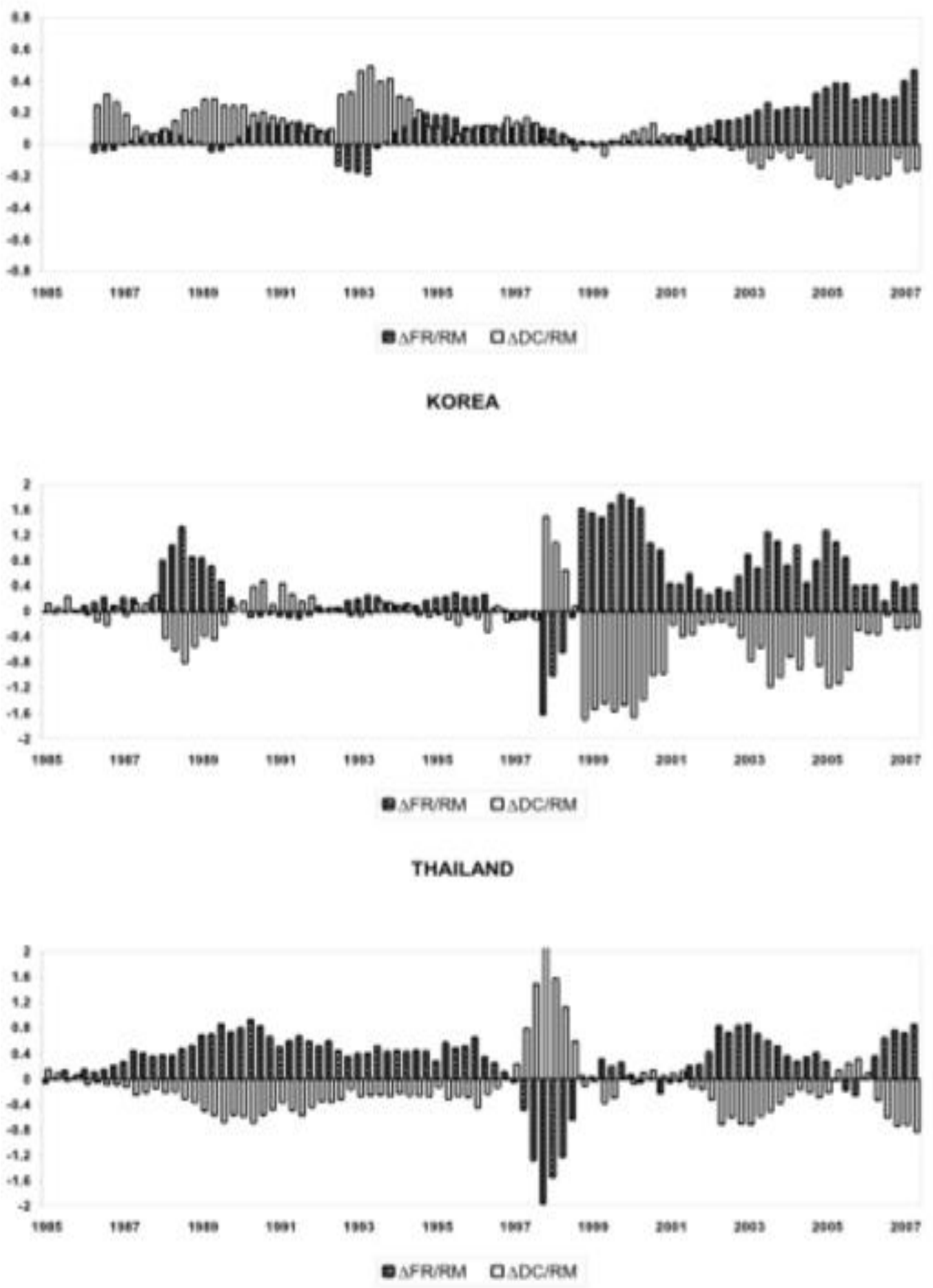
FiguRE 3

Foreign Reserve on GDP and External Deb on GDP

Turkey, from 1995 to 2010

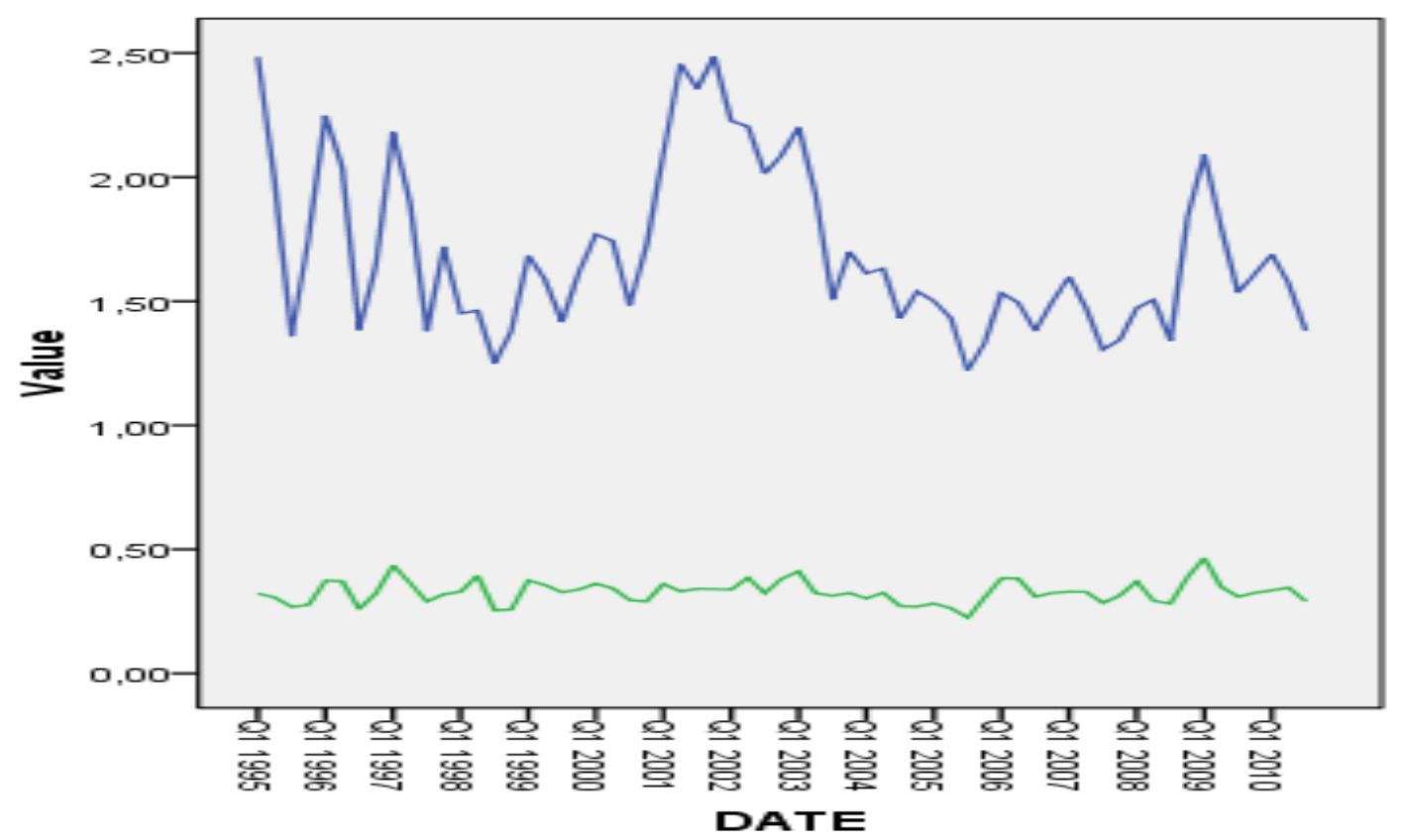

GED_GDP
NFA_GDP

Lebanon, from 1995 to 2010

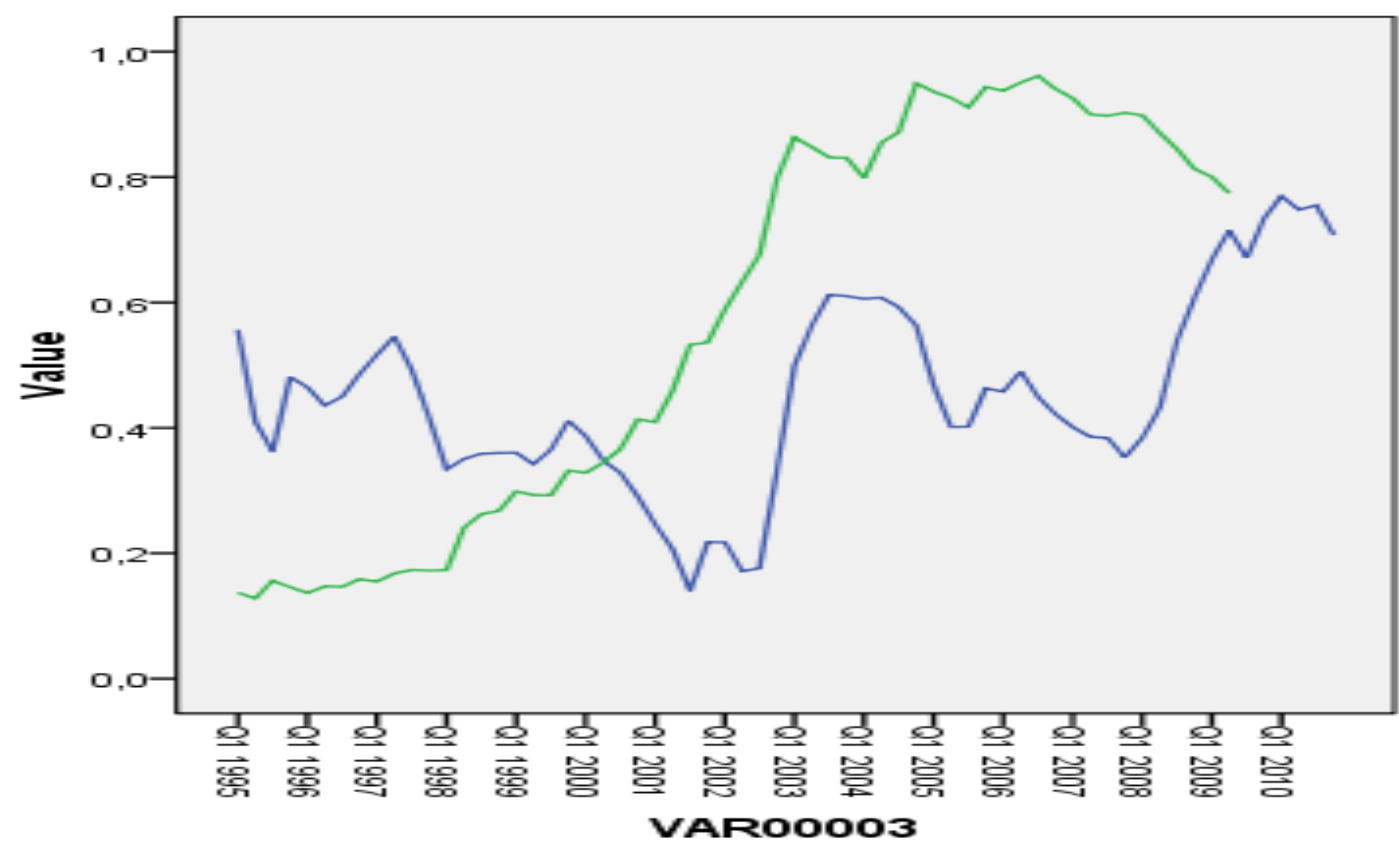


Figure 4

Variation of NDA/RM and NFA/RM

Lebanon : (Source Author's data)

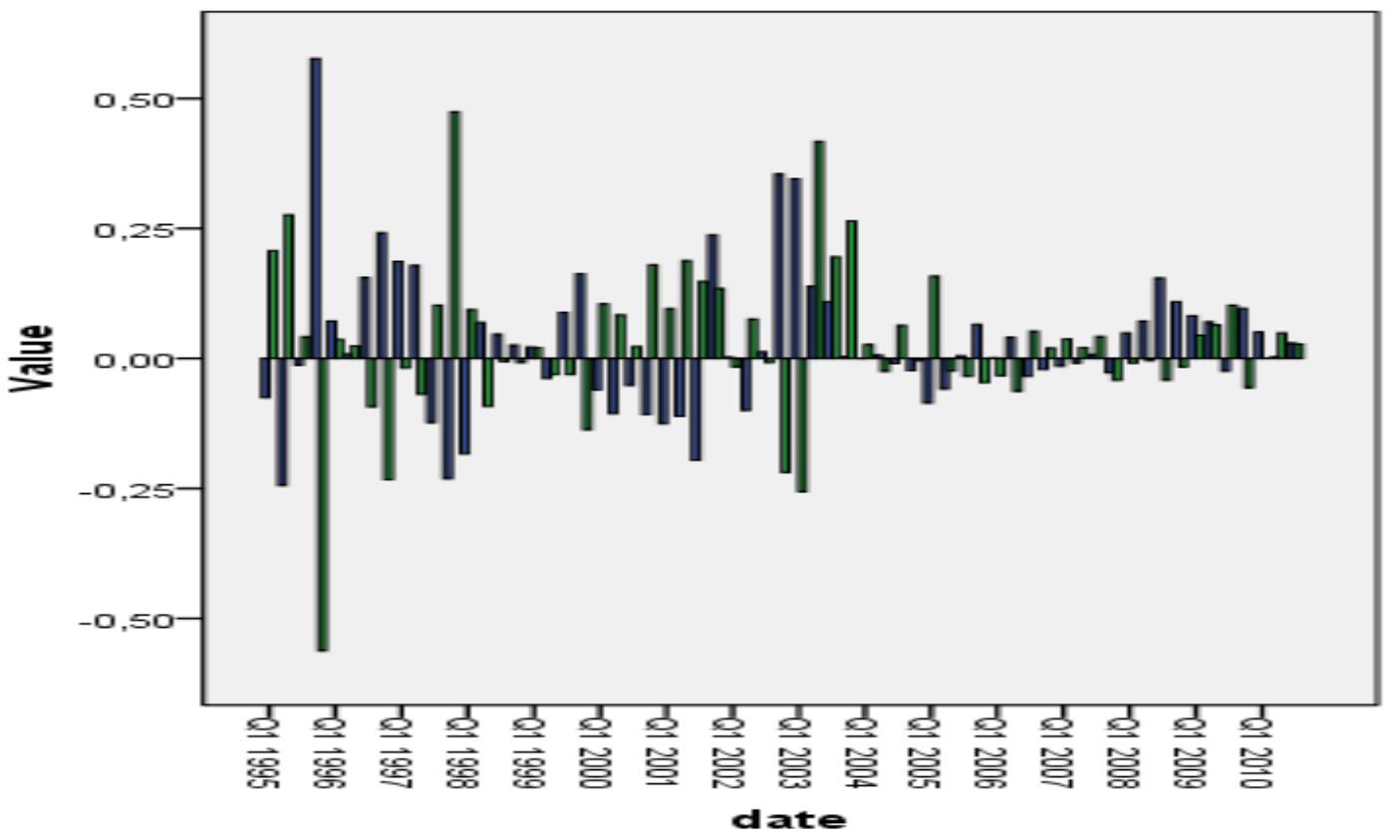

$\square$ nifa

Turkey: (Source Author's data)

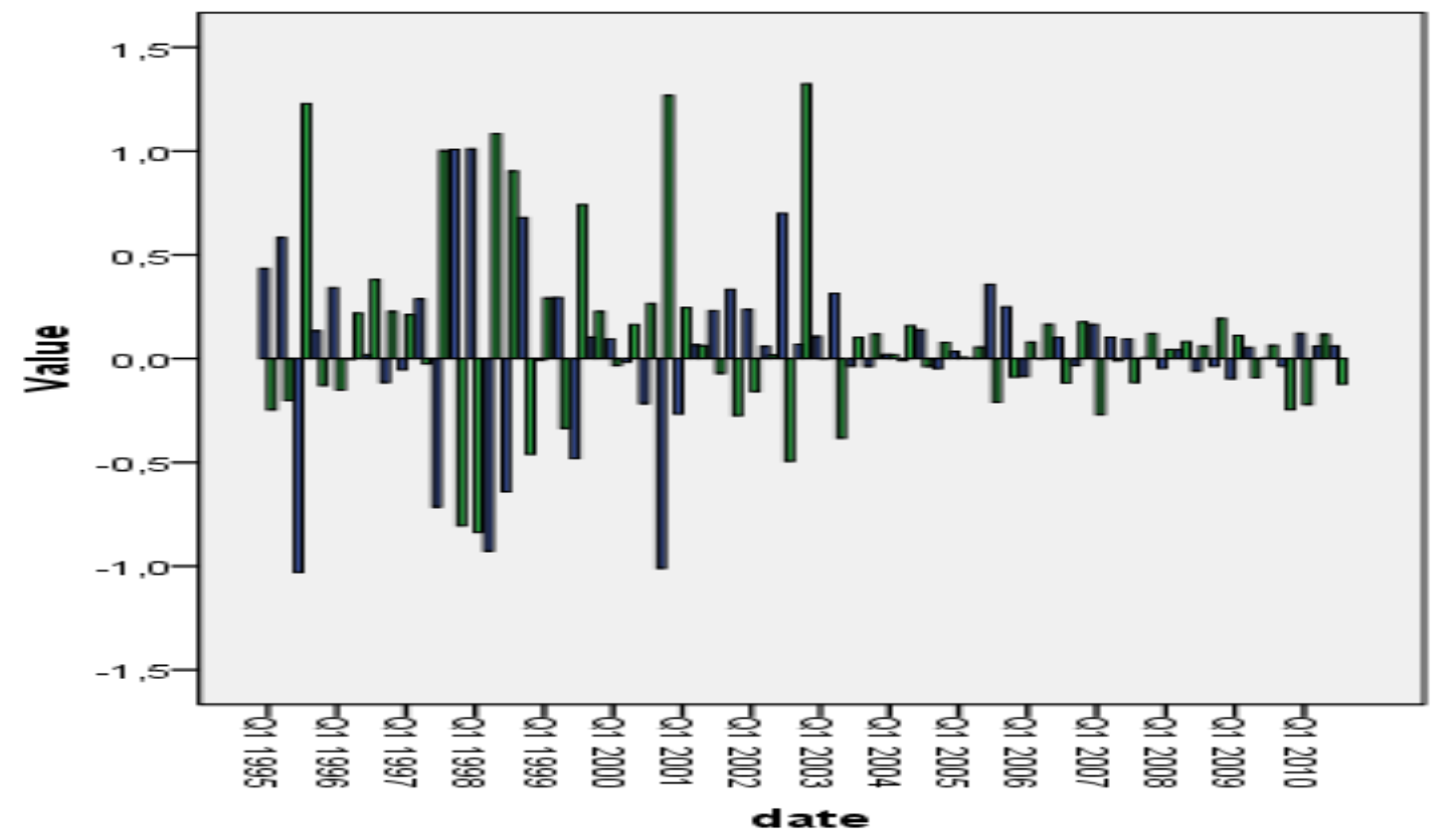

$\square$ vria_T

28 The blue indicates the $\Delta \mathrm{NFA}_{\mathrm{t}} / \mathrm{RM}_{4}$ and the green indicates the $\Delta \mathrm{NDA}_{\mathrm{t}} / \mathrm{RM}_{4}$ 


\section{Figure 5 \\ Import and Export from 1995-2010}

Lebanon: In Billion Local Currencies

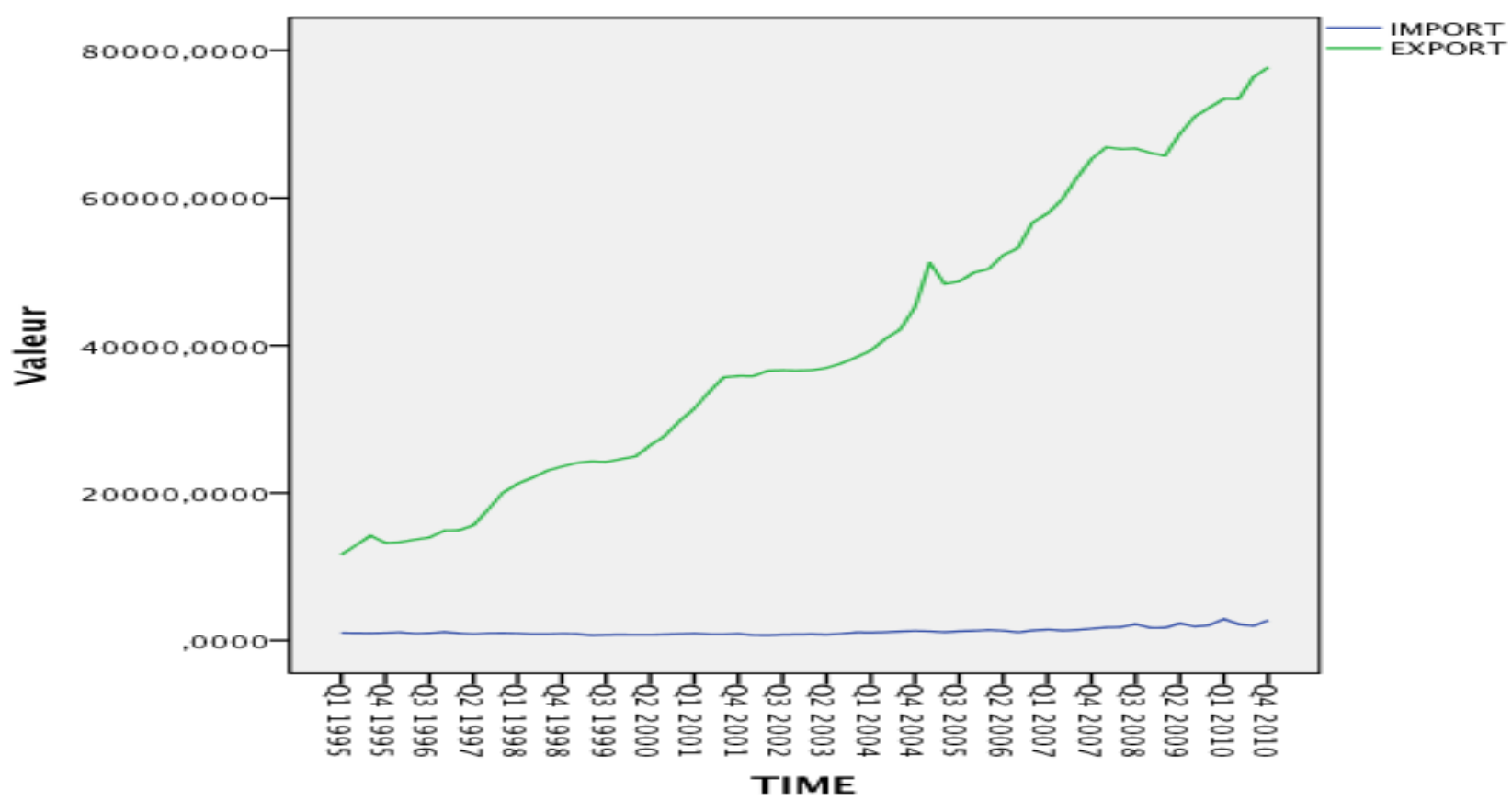

Turkey In Million Local Currencies

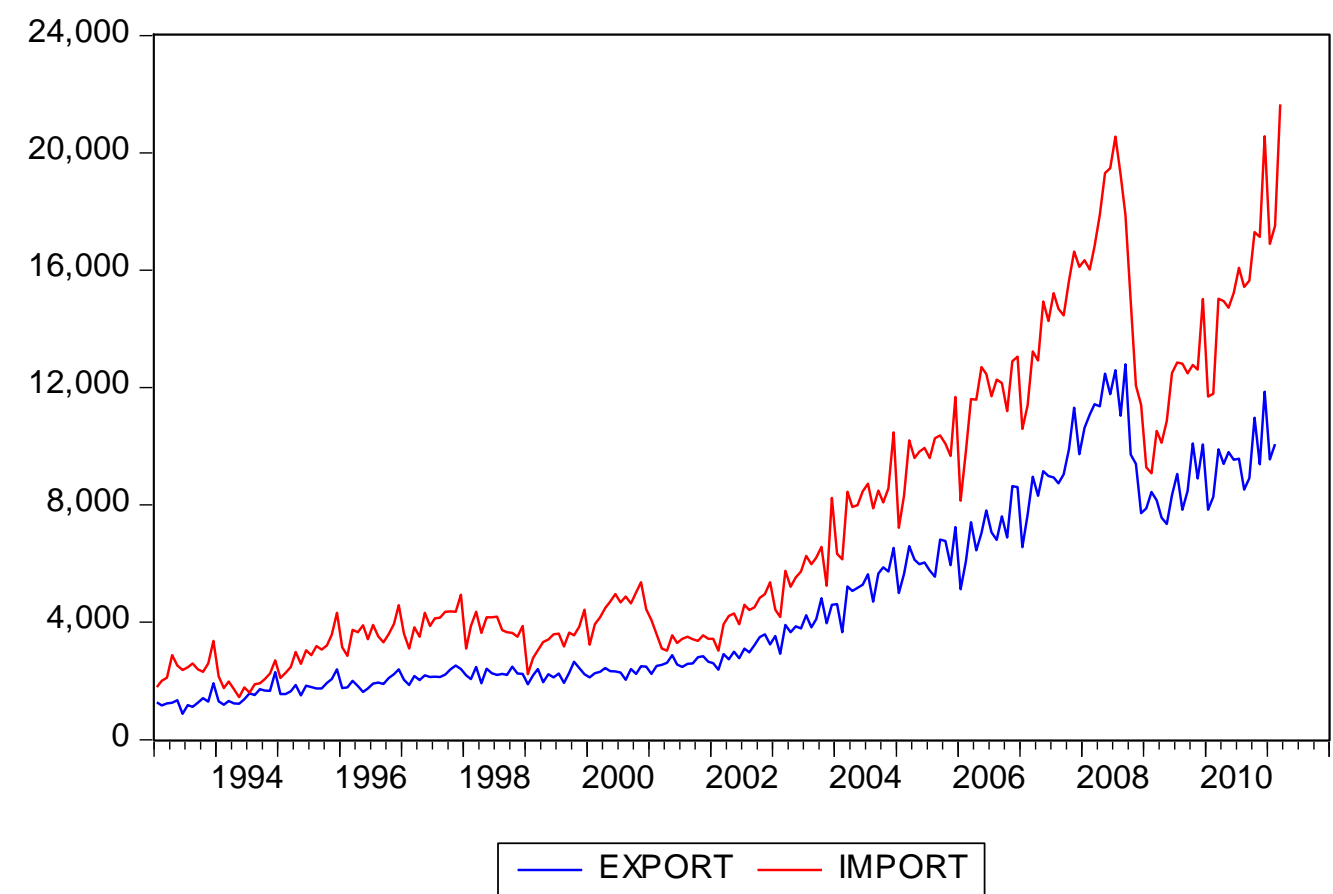

Source: central bank of Turkey : http://www.tcmb.gov.tr/ 
Figure 6

Gross External debt and Net Foreign Asset from 1995-2010

Turkey In Million Local Currencies

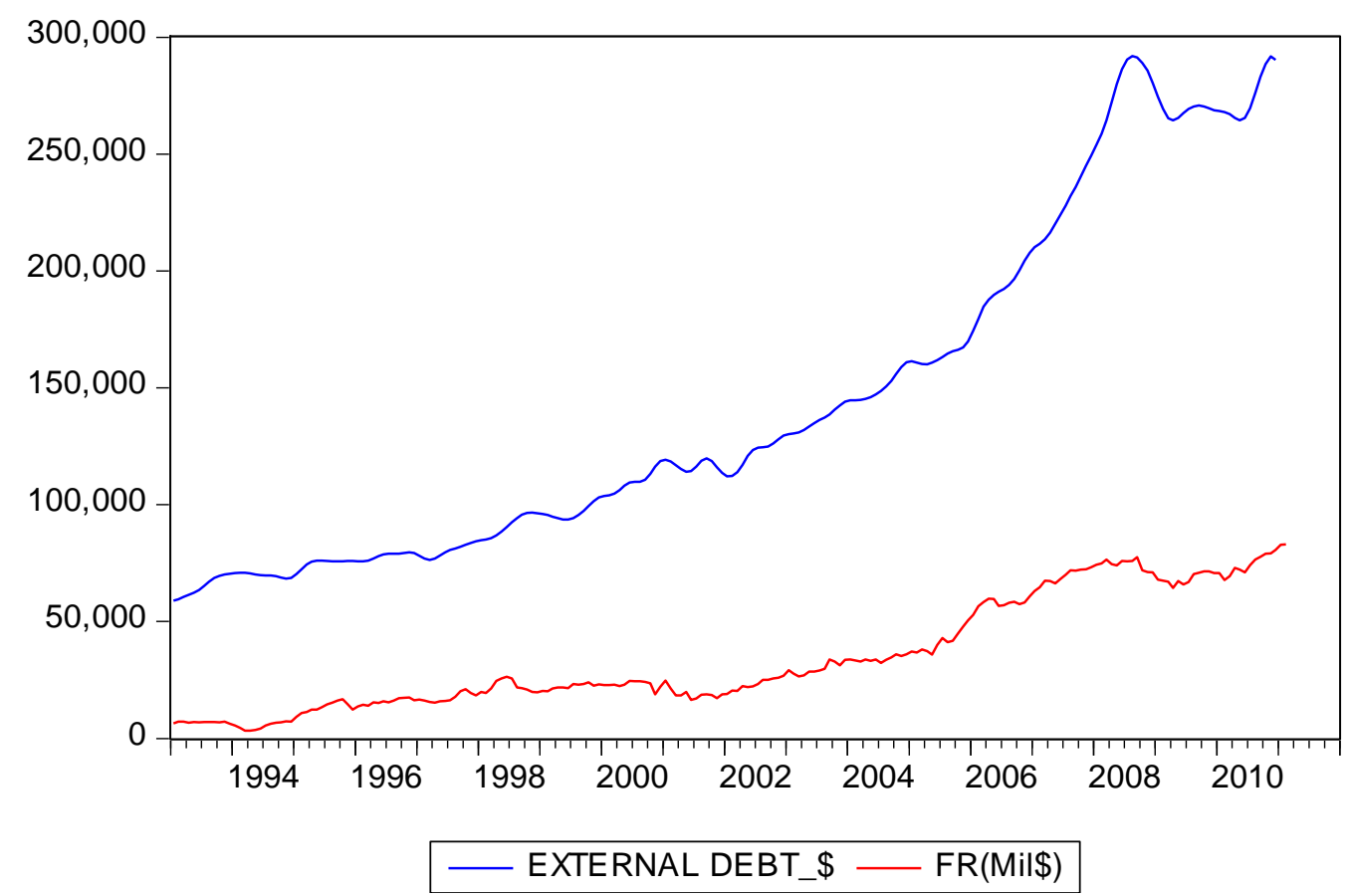

Source: central bank of Turkey : http://www.tcmb.gov.tr/

Lebanon In Billion Local Currencies

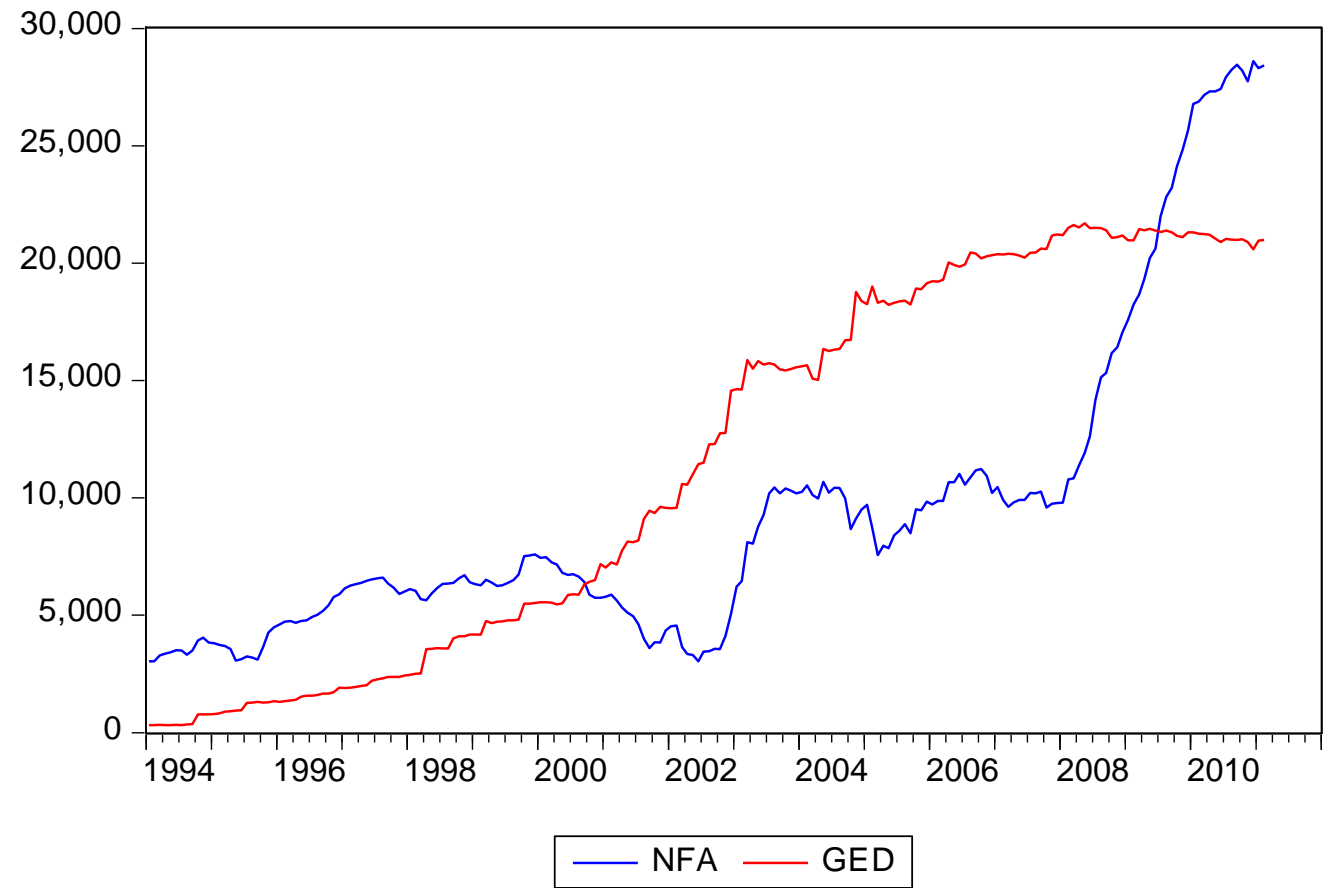


Figure 7

Interest rate on deposit (6 months)

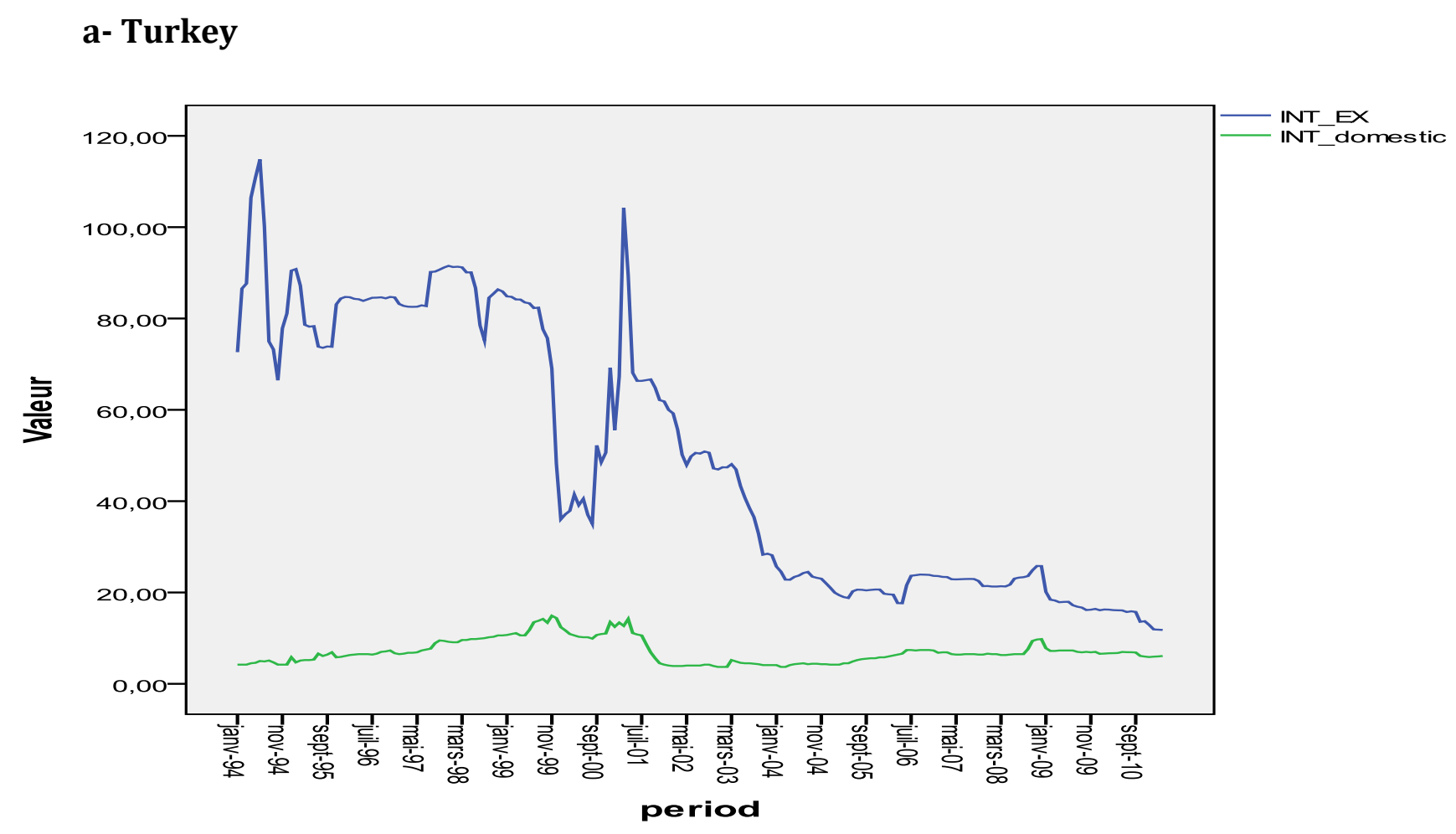

Source: central bank of Turkey : http://www.tcmb.gov.tr/

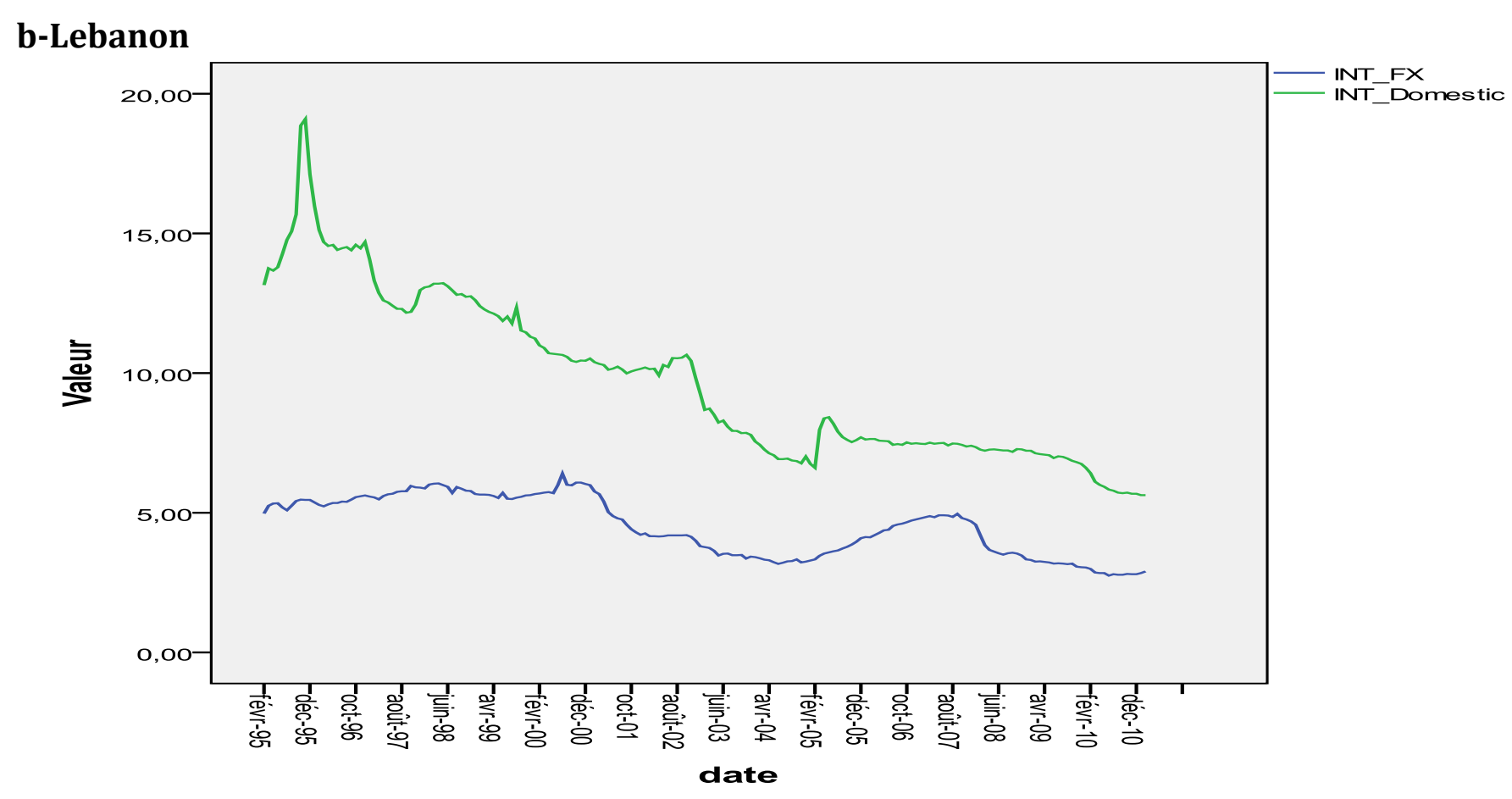


Figure 8

Exchange rate

\section{a-Turkey}

EXC

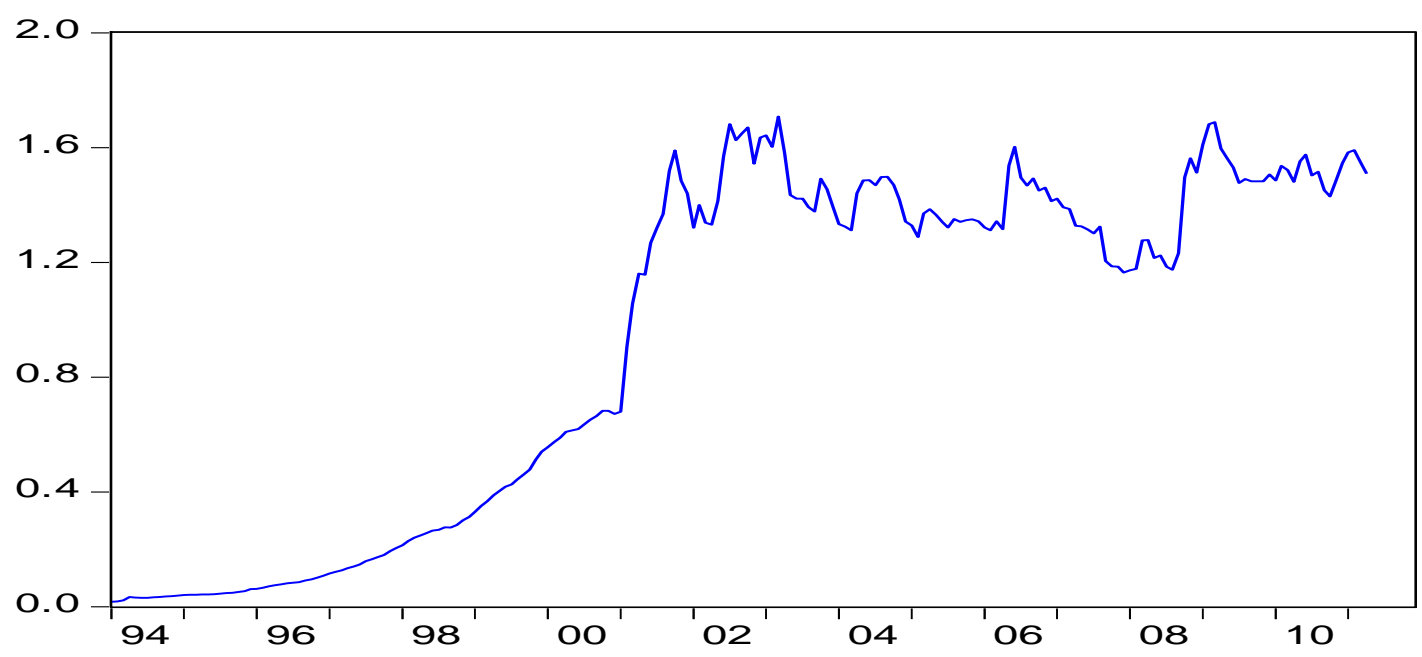

\section{b-Lebanon}

\section{EXC}

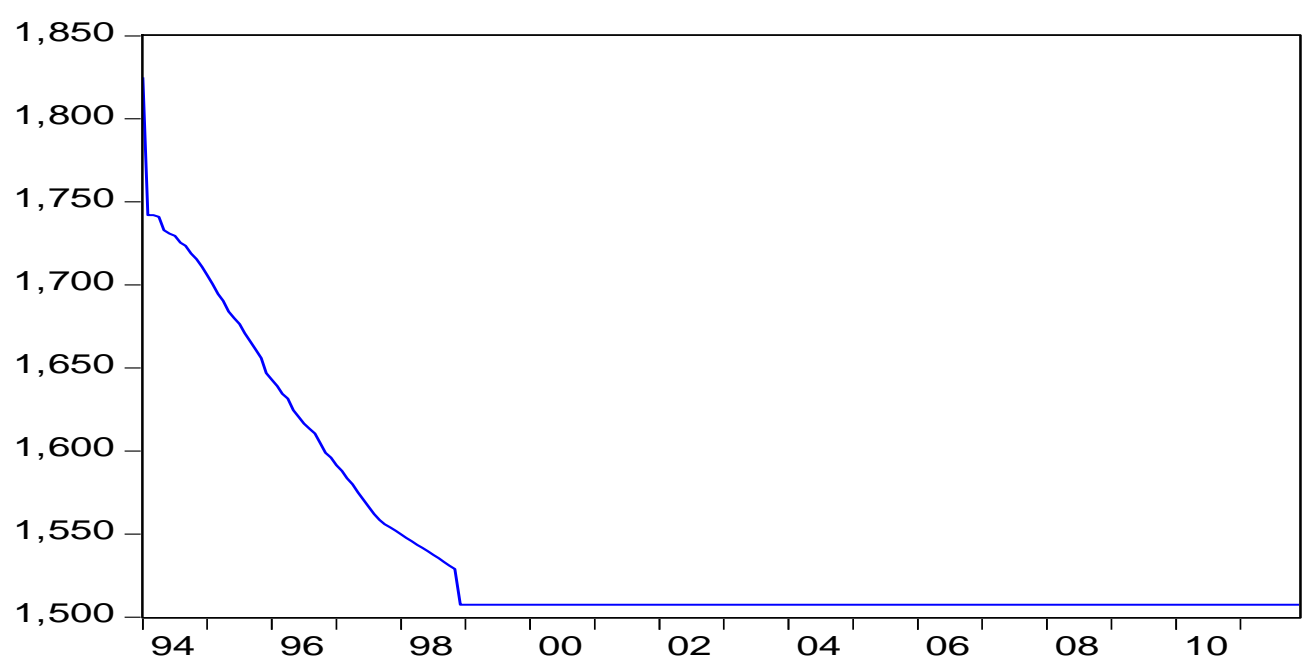


